FEDERAL RESERVE BANK OF SAN FRANCISCO

WORKING PAPER SERIES

\title{
How do Trade and Financial Integration Affect the Relationship between Growth and Volatility
}

\author{
M. Ayhan Kose \\ International Monetary Fund \\ Eswar S. Prasad \\ International Monetary Fund \\ and \\ Marco E. Terrones \\ International Monetary Fund
}

May 2004

Working Paper 2004-29

http://www.frbsf.org/publications/economics/papers/2004/wp04-29bk.pdf

This paper was presented at the conference on "Emerging Markets and Macroeconomic Volatility: Lessons from a Decade of Financial Debacles" cosponsored by the Center for Pacific Basin Studies of the Federal Reserve Bank of San Francisco and the Center for International Economics at the University of Maryland and held at the FRBSF on June 4-5 2004. The views in this paper are solely the responsibility of the authors and should not be interpreted as reflecting the views of the Federal Reserve Bank of San Francisco or the Board of Governors of the Federal Reserve System 
$\underline{\text { Preliminary }}$

\title{
How Do Trade and Financial Integration Affect the Relationship between Growth and Volatility?
}

\author{
M. Ayhan Kose, Eswar S. Prasad and Marco E. Terrones ${ }^{1}$
}

May 31, 2004

\begin{abstract}
The influential work of Ramey and Ramey (1995) highlighted an empirical relationship that has now come to be regarded as conventional wisdom - that output volatility and growth are negatively correlated. We reexamine this relationship in the context of globalization - a term typically used to describe the phenomenon of growing international trade and financial integration that has intensified since the mid-1980s. We employ various econometric techniques and a comprehensive new dataset to analyze the link between growth and volatility. Our findings suggest that, while the basic negative association between growth and volatility has been preserved during the 1990s, both trade and financial integration attenuate this negative relationship. Specifically, countries that are more open to trade appear to face a less severe tradeoff between growth and volatility. We find a similar, although slightly less robust, result for the interaction of financial integration with volatility. We also investigate some of the channels, including investment and credit, through which different aspects of global integration could affect the growth-volatility relationship.
\end{abstract}

${ }^{1}$ International Monetary Fund, 700 19th Street, N.W., Washington D.C. 20431 akose@imf.org; eprasad@imf.org; mterrones@imf.org. We thank Olivier Jeanne, Andy Rose, Carlos Vegh, and Kamil Yilmaz for their useful suggestions. We thank Smita Wagh for excellent research assistance. The views expressed in this paper are those of the authors and do not necessarily represent those of the IMF. 


\section{Introduction}

The influential work of Ramey and Ramey (1995) highlighted an empirical relationship that has now come to be regarded as conventional wisdom - that volatility and growth are negatively correlated. This is an important result since it implies that policies and exogenous shocks that affect volatility can also influence growth. Thus, even if volatility is considered intrinsically a second-order issue, its relationship with growth suggests that volatility could indirectly have first-order welfare implications.

How do trade and financial integration affect the relationship between growth and volatility? In this paper, we attempt to answer this question, which has taken on increasing importance in view of the significant increases in the volumes of international trade and financial flows over the last four decades. While cross-country trade linkages have been rising steadily over the last four decades, there has been a substantial increase in cross-border capital flows among industrial economies and across industrial and developing economies since the mid1980s. However, while the spread of trade linkages has been more broad-based, only a relatively small group of developing economies, often referred to as "emerging markets," have undergone significant financial integration, as measured by gross capital flows across their borders. ${ }^{2}$ Many of these economies have experienced high growth but have also been subject to high volatility, most prominently in the form of severe financial crises that befell many of them during the last decade and a half.

These developments naturally lead to the question of whether, in a more integrated global economy, the relationship between growth and volatility has changed. More specifically, do the high growth rates in emerging markets that are presumably partly fueled by financial flows come at the cost of higher volatility associated in part with the vagaries of international trade and financial flows? The change over time in the relative vulnerability of industrial and developing economies to external crises also raises questions about whether the growth-volatility relationship is influenced by the "growing pains" seemingly associated with rising trade and financial integration. In other words, are the level of a country's development and the extent of its integration into international markets important in determining the conditional validity of this

\footnotetext{
${ }^{2}$ For an extensive documentation of changes in the volume of international financial flows, Lane and Milesi-Ferretti (2001, 2003), and Kose, Prasad, and Terrones (2004).
} 
relationship? In this context, while there appears to be a general consensus that openness to trade flows stimulates domestic growth, it also appears to be the case that such openness increases vulnerability to external shocks, including highly volatile terms of trade shocks. The effects of financial integration are less obvious. Clearly, a more detailed analysis of this question is therefore warranted.

In addressing the question stated in the title, our paper has two main objectives. First, we explore how this relationship has been influenced by different aspects of globalization. The Ramey and Ramey results, which have become the benchmark in this literature, are based on a dataset that ends in 1985, just when the pace of globalization began to pick up and enveloped a number of developing countries as well. Some recent papers show that the negative relationship between growth and volatility has persisted into the $1990 \mathrm{~s}^{3}$ However none of these papers provide a rigorous analysis of the role of rising trade and financial linkages in influencing this relationship. Financial globalization, in particular, is likely to have been an important factor influencing this relationship during the past twenty years, especially as increased international financial flows appear to have precipitated sudden episodes of high volatility in many developing economies. A central contribution of this paper is a comprehensive analysis of the roles of both trade and financial integration in driving the growth-volatility relationship.

Understanding the channels through which volatility could potentially influence growth is also of considerable interest. A related issue is whether there are common factors that affect both growth and volatility and how these common factors interact with the forces of globalization in accounting for the empirical link between volatility and growth. Thus, the second objective of this paper is to provide a comprehensive analysis of such determinants, including investment, credit growth, development of domestic financial sector, and the quality of institutions. The impact of these common factors on influencing the individual dynamics of growth and volatility has been examined in some recent papers, which are discussed in the next section. However, our understanding of these factors along with the role played by increased international economic linkages in explaining the relationship between growth and volatility is quite limited.

\footnotetext{
${ }^{3}$ Fatas (2003) and Loayza and Hnatkovska (2003) update the regressions in Ramey and Ramey (1995) using recent data and find that the negative relationship between growth and volatility is preserved.
} 
In section II, we present a review of recent studies analyzing how globalization affects growth and also how it affects volatility. In addition, we provide a summary of several theoretical and empirical studies focusing on the relationship between growth and volatility. This survey suggests that neither theoretical studies nor empirical ones have rigorously examined the effects of increased trade and financial linkages on the growth-volatility relationship.

In section III, we describe the dataset used in the analysis. The main features of the dataset are that is has a broad coverage, comprising 85 countries, both industrial and developing, and annual data over the period 1960-2000. Another important feature of this dataset is that it includes a comprehensive set of measures of trade and financial integration for these countries. In section IV, considering the important implications of the timing of the intensification of trade and financial linkages across national economies for our main question, we document some empirical evidence about the impressive growth of these linkages over the past four decades.

In section $\mathrm{V}$, we provide a variety of stylized facts about the changes in the dynamics of growth and volatility over time and across countries. We detect a number of interesting patterns in the relationship between growth and volatility, which has been changing over time and across different country groups. We also use an event study approach to examine how growth and volatility change before and after trade and financial liberalizations. Both types of liberalizations are typically associated with increases in output and investment growth, but the changes in the volatility of output and consumption growth after such liberalization programs do not follow a clear pattern.

This sets the stage for the more formal empirical analysis in section VI, where we use various regression models to analyze the determinants of the growth-volatility relationship. We first examine the empirical validity of the main Ramey-Ramey result when data for the post1985 period, which was a turbulent period for many developing economies, are included in the analysis. We find that the basic empirical result of a negative cross-sectional association between volatility and growth holds up even in the 1990s. More importantly, however, we find that the result is sensitive to the choice of country groups. For example, the results indicate that, while there is a significant positive relationship among industrial countries, the relationship is significantly negative among developing countries. Moreover, the association between growth and volatility in developing countries depends on the extent of financial integration. In more 
financially integrated economies, the relationship appears to be positive, whereas in less financially integrated ones it is negative.

We then use cross-section and panel regressions to conduct a more formal analysis of the growth-volatility relationship, including an examination of how trade and financial linkages may have affected this relationship. Using measures of average growth and volatility in each decade, we find that the negative relationship between growth and volatility survives when we include standard controls from the growth literature and account for the interaction between volatility and different measures of global integration.

The main result of the paper is that trade and financial integration appear to attenuate the negative growth-volatility relationship. Specifically, in regressions of growth on volatility and other control variables, we find that the estimated coefficients on interactions between volatility and trade integration are significantly positive. In other words, countries that are more open to trade appear to face a less severe tradeoff between growth and volatility. We find a similar, although slightly less robust, result for the interaction of financial integration with volatility.

The results also imply a threshold in the growth-volatility relationship. Beyond a certain level of trade and/or financial integration, this relationship appears to turn positive. This helps reconcile the findings that the growth-volatility relationship is negative for developing countries but positive for industrial economies, since the latter group has, on average, higher levels of trade and, especially, financial integration compared to the developing countries in our sample.

In section VII, we report a variety of robustness checks of our main results. We first study the impact of other control variables, representing various channels linking volatility to growth. We then consider different regression frameworks to further examine the robustness of our results. In particular, we employ fixed effects regressions to capture country specific effects, Least Absolute Deviation regressions to check the role of outliers in driving the main findings, and account for the endogeneity of the growth-volatility relationship using IV regressions. The results indicate that the main findings of the paper are robust to potential problems associated with fixed effects, endogeneity and the presence of outliers. Section VIII concludes with a brief summary of results and directions for future research. 


\section{Review of Economic Theory and Empirical Studies}

This section provides a brief review of theoretical and empirical studies about the impact

of globalization on the dynamics of volatility and growth and about the relationship between growth and volatility. Our review focuses on three branches of a rapidly burgeoning literature on the role of various global forces in driving economic growth and volatility. We first review the literature studying the impact of increased global linkages on economic growth. We then turn our attention to the literature on the relationship between globalization and macroeconomic volatility. Finally, we summarize the literature studying various theoretical and empirical linkages between growth and volatility. In each sub-section, we first discuss the main predictions of theoretical studies, and then survey the empirical research.

There are four major points to be taken from our brief survey. First, economic theory suggests that globalization should have a positive impact on growth, but does not provide strong predictions about its impact on volatility or about its effects on the relationship between growth and volatility. Second, empirical research indicates that increasing trade openness is associated with both higher growth and more volatility, but the effects of financial openness on growth and volatility are far less clear. Third, several recent empirical studies appear to find a negative relationship between growth and volatility, both in unconditional terms and controlling for a variety of standard determinants of growth.

The fourth issue, which provides a point of departure for this paper from the existing literature, is that neither theoretical studies nor empirical ones have rigorously examined the effects of increased trade and financial linkages on the growth-volatility relationship. In our view, rising global linkages constitute one of the most important economic phenomena over the last two decades in terms of understanding how business cycle volatility and long-run growth are related. Figure 1 provides a rough schematic description summarizing the results of the existing empirical literature.

\section{II.1. Effects of Globalization on Growth}

Various theoretical models emphasize the importance of trade openness in promoting economic growth. Some of these theoretical models focus on static gains, including the gains derived from comparative advantage considerations. Others consider knowledge spillovers associated with international trade (Grossman and Helpman (1991)). Some other studies focus on 
the indirect links between trade openness and growth that operate through the positive effect of trade on productivity and investment growth (Levine and Renelt (1992) and Baldwin and Seghezza (1998)). ${ }^{4}$

In theory, there are various direct and indirect channels through which increased financial flows can enhance growth. ${ }^{5}$ The direct channels include augmentation of domestic savings, reduction in the cost of capital through better global allocation of risk, development of the financial sector (Levine (1996) and Caprio and Honohan (1999)), and transfer of technological know-how. The main indirect channels are associated with promotion of specialization (KalemliOzcan, Sorensen, and Yosha (2003)) and inducement for better economic policies (Gourinchas and Jeanne (2003)).

There is a large empirical literature suggesting that openness to trade has a positive impact on growth. For example, using a variety of methods, several researchers, including Dollar (1992), Ben-David (1993), Sachs and Warner (1995), Frankel and Romer (1999), Dollar and Kraay (2002) and Wacziarg and Welch (2003), show that trade openness helps promote economic growth. Rodriquez and Rodrik (2001) challenge the robustness of some of these findings and argue that several of these studies suffer from problems associated with model misspecification and the use of openness measures that may be capturing other policy or institutional features.

By contrast to the literature on trade and growth, recent empirical research is unable to establish a clear link between financial integration and economic growth. The majority of empirical studies find that financial integration has no effect or at best a modest effect on economic growth. For example, Edison, Levine, Ricci, and Slok (2002) employ a regression model that controls for possible reverse causality and conclude that there is no robustly significant effect of financial integration on economic growth.

Another set of empirical studies suggests that the composition of capital flows determines the effects of financial integration on economic growth (Reisen and Soto (2001) and Goldberg

\footnotetext{
${ }^{4}$ Krueger and Berg (2002), Baldwin (2003), and Winters (2004) provide extensive surveys of the literature on trade and growth. There is also a large literature studying the impact of preferential trade agreements on economic growth and welfare (Baldwin and Venables (1995)).

${ }^{5}$ Prasad, Rogoff, Wei, and Kose (2003) provide a review of theoretical and empirical studies that analyze the effects of financial integration on economic growth.
} 
(2004)). In particular, these studies conclude that FDI flows tend to be positively associated with output growth in those countries that have a sufficient level of human capital (Borenzstein, De Gregorio, and Lee (1998)) and well-developed domestic financial markets (Alfaro, Chanda, Kalemli-Ozcan, and Sayek (2003)). Other studies focus on the impact of equity market liberalization on the growth rates of output and investment. Bekaert, Harvey, and Lundblad (2001) find that equity market liberalization induces a significant increase in the growth rate of output and Henry (2000) documents that it leads to a substantial increase in the growth rate of investment.

\section{II.2. Effects of Globalization on Volatility}

The theoretical impact of increased trade and financial flows on output volatility depends on various factors, including the composition of these flows, patterns of specialization, and the sources of shocks. For example, if trade openness is associated with increased specialization of

countries' production structures (at the industry level) and industry-specific shocks are important in driving business cycles, it could lead to an increase in output volatility. However, if rising trade flows are associated with increased vertical specialization across countries, which would lead to a larger volume of trade in intermediate inputs, then the volatility of output growth could decline (Kose, Prasad, Terrones (2003a)).

In theory, financial integration could help lower the volatility of macroeconomic fluctuations in capital-poor developing countries by providing access to capital that can help them diversify their production base. Rising financial integration, however, could also lead to increasing specialization of production based on comparative advantage considerations, thereby making economies more vulnerable to industry-specific shocks (Kalemli-Ozcan, Sorensen, and Yosha (2003)). In addition, sudden changes in the direction of capital flows could induce boombust cycles in developing countries, most of which do not have deep enough financial sectors to cope with volatile capital flows (Aghion, Banerjee, and Piketty (1999)). Results from dynamic stochastic general equilibrium business cycle models suggest that increased access to international financial markets should dampen the volatility of consumption while inducing an increase in investment volatility (Mendoza (1994), Backus, Kehoe, Kydland (1995) and Baxter and Crucini (1995)). 
Recent empirical work has been unable to establish a clear link between stronger trade linkages and macroeconomic volatility. While some studies find no significant relationship between an increased degree of trade interdependence and domestic macroeconomic volatility (Buch, Dopke, and Pierdzioch, 2002), others find that an increase in the degree of trade openness leads to higher output volatility, especially in developing countries (Karras and Song (1996), Easterly, Islam, and Stiglitz, 2001). Kose, Prasad, and Terrones (2003a) find that, while trade openness increases the volatility of output and consumption growth in emerging market economies, it reduces the volatility of consumption growth relative to that of income growth, implying that trade improves risk-sharing possibilities.

Kose, Prasad, and Terrones (2003a) document that financial integration does not have a statistically significant impact on the volatility of output growth. They also argue that the relationship between financial integration and consumption growth volatility is a nonlinear one-increased financial integration is associated with rising relative volatility of consumption, but only up to a certain threshold. Bekaert, Harvey, and Lundblad (2002) find that domestic equity market liberalizations are associated with lower volatility of output and consumption growth. IMF (2002) also provides evidence indicating that financial openness is associated with lower output volatility in developing countries.

\section{II.3. The Relationship between Growth and Volatility}

Whether volatility and growth should be investigated independently, rather than studied as related phenomena, has been the subject of some debate. Papers in the stochastic dynamic business cycle literature have typically propounded the view that the distinction between trend and cycles is an artificial one, since both growth and fluctuations are driven by the same set of shocks. However, there is no clear implication that can be derived from these models about the relationship between volatility and growth. Jones, Manuelli, and Stacchetti (1999) show that, in an endogenous growth model, the relationship between volatility and growth can be either positive or negative depending on the curvature of the utility function. Jovanovic (2003), on the other hand, argues that there is a negative relationship between growth and volatility in an endogenous growth model, since rates of growth are more volatile in recessions than in booms.

Various theoretical channels, which can lead to a negative relationship between growth and volatility, are discussed in the literature. For example, some theoretical models argue that the 
link between growth and volatility depends on the dynamics of investment. Bernanke (1983), Pindyck (1988), and Aizenman and Marion (1993) construct models in which irreversibilities and/or the presence of asymmetric adjustment costs in investment could lead to higher volatility and lower investment, which in turn reduces economic growth. Using a growth model with learning by doing, Martin and Rogers $(1997,2000)$ emphasize the importance of costs associated with learning in determining the nature of the relationship between growth and volatility. They conclude that there is a negative relationship between economic growth and volatility because the adverse impact of recessions on learning by doing dominates the beneficial effects of expansions. ${ }^{6}$ In the context of an endogenous growth model, Mendoza (1997) shows that termsof-trade fluctuations can also affect the relationship between growth and volatility. While there is a positive relationship between average changes in the terms of trade and economic growth, volatility associated with terms of trade fluctuations could lead to slower growth, depending on the degree of risk aversion.

There are some theoretical studies arguing that macroeconomic volatility could have a beneficial impact on economic growth. For example, Aghion and Saint-Paul (1998) show that recessions could decrease the costs associated with innovations and lead to improvements in productivity and higher economic growth. Blackburn (1999) finds that volatility could promote economic growth in an endogenous growth model and argues that stabilization policies could have harmful effects on the growth performance of an economy. Tornell, Westermann, and Martinez (2004) argue that the presence of credit market imperfections in financially open economies could lead to increased volatility and higher growth. In particular, they argue that financial integration leads to higher growth in developing countries, but often results in economic crises as well because of various credit market imperfections.

Direct empirical examinations of the relationship between output volatility and growth date back to contributions by Kormendi and Maguire (1985) and Grier and Tullock (1989), who

\footnotetext{
${ }^{6}$ Caballero (1991) shows that the relationship between volatility and investment growth depends on the nature of competition and scale economies. While the relationship is positive with perfect competition and constant returns to scale in production, it becomes negative in a model with imperfect competition and decreasing returns to scale. Stiglitz (1993) analyzes the role of capital market imperfections and concludes that volatility could have an adverse impact on productivity and economic growth. Bean (1991), Saint-Paul (1993), and Acemoglu and Zilibotti (1997) also show that volatility can have a dampening effect on economic growth.
} 
suggest that there is a positive relationship between volatility and growth. On the other hand, in an influential contribution that has since acquired the status of conventional wisdom, Ramey and Ramey (1995; henceforth referred to as RR) conclude that growth and volatility are negatively related. Using a dataset comprising 92 countries and covering the period 1950-1985, they show that the relationship is robust after introducing various control variables, including the share of investment in GDP, population growth, human capital, and initial GDP. They also find that volatility associated with government expenditure is negatively associated economic growth. The basic RR result has intuitive appeal since volatility, especially on the order of magnitude typically experienced by developing economies, could presumably have some longer-term adverse implications on economic activity. RR also show that the results of earlier empirical studies suggesting a positive relationship between growth and volatility, including Kormendi and Maguire (1985), might be misleading since these studies include the volatility of monetary shocks, which may be correlated with the volatility of output, as an explanatory variable.

More recent work using different methodologies and datasets tends to confirm the negative relationship between volatility and growth. Martin and Rogers (2000) find similar evidence using three different samples_-data for 90 European regions over the period 19791992; 24 developed countries for the period 1960-88; and a broader sample of 72 developed and developing countries for the same period. Their results indicate that there is a significant negative relationship between growth and the amplitude of business cycles in developed countries. However, they are unable to find a statistically significant relationship for the group of developing countries. ${ }^{7}$

Fatas (2003), using a broad sample of about 100 countries and data over the period 196098, explores the effects of using different control variables and different measures of volatility. He concludes that the negative growth-volatility relationship is robust. He also notes that the use of a basic volatility measure, such as the standard deviation of output growth, or an alternative

\footnotetext{
${ }^{7}$ In a recent paper, Imbs (2004) attempts to reconcile the positive relationship between growth and volatility at the sectoral level with the negative relationship at the country level. He notes that how this relationship at the sectoral level translates into the relationship at the aggregate level depends on the degree of synchronicity of fluctuations across sectors and on the relative importance of aggregate versus sector-specific shocks.
} 
measure of uncertainty, such as the residuals from a regression of output growth from a simple autoregressive forecasting equation, makes no difference to the results.

Loayza and Hnatkovska (2003) study the growth-volatility relationship using a sample of 79 developed and developing countries over the period 1960-2000. They confirm that the relationship is robustly negative when numerous controls from the growth literature are incorporated into their regression framework. They also conclude that the negative relationship has intensified in the last two decades, mostly as a result of large recessions rather than normal cyclical fluctuations. Both Fatas (2003) and Loayza and Hnatkovska (2003) also control for trade openness in their regressions, but their results indicate that the trade openness variable has no significant impact on the relationship between volatility and growth.

Some other empirical studies focus on the impact of a particular source of volatility on economic growth. For example, Fatas and Mihov (2003) find that volatility associated with the fiscal policy induces lower economic growth. Judson and Orphanides (1996) establish a negative relationship between inflation volatility and economic growth while Barro (1991) and Alesina, Ozler, Roubini and Swagel (1996) study the adverse impact of political instability on growth. Mendoza (1997) and Turnovsky and Chattopadhyay (2003) document evidence of the negative impact of terms of trade volatility on growth. ${ }^{8}$ Tornell, Westermann, and Martinez (2004) provide evidence indicating that, while the standard deviation of credit growth has a negative impact on growth of GDP, negative skewness (bumpiness) of credit growth has a positive impact.

Some recent papers have considered the roles of other factors such as financial market development and quality of institutions in explaining the dynamics of volatility and growth. Denizer, Iyigun, and Owen (2002) and Beck, Lundberg, and Manjoni (2001) find that economies with more developed financial markets display less volatile output, consumption, and investment fluctuations while King and Levine (1993) and Rajan and Zingales (1998) find that countries with more developed financial markets are able to grow faster. Acemoglu, Johnson, Robinson,

\footnotetext{
${ }^{8}$ Catão and Kapur (2004) find that volatility of output plays a major role in determining the sovereign risk of several developing countries. In particular, they argue that there is a positive association between volatility and the probability of default. This could be another channel through which volatility has a negative impact on economic growth.
} 
and Thaicharoen (2003) document that countries with weak institutions are more likely to experience high volatility and lower economic growth.

\section{Dataset}

We study the relationship between growth and volatility using a large dataset that includes industrial as well as developing countries. While the basic dataset we use is the latest version of the Penn World Tables (Heston, Summers, and Aten, 2002), we supplement that with data from various other sources, including databases maintained by the World Bank and IMF. The dataset comprises annual data over the period 1960-2000 for a sample of 85 countries - 21 industrial and 64 developing. It is possible to employ a more comprehensive country coverage for the basic growth-volatility regressions used in RR. However, our main objective is to analyze how trade and financial openness affect this basic relationship and the data on financial openness turned out to be a major constraint to expanding the coverage of the dataset any further.

For the descriptive analysis in the next two sections, we divide developing countries into two coarse groups - more financially integrated (MFI) economies and less financially integrated (LFI) economies. There are 23 MFI and 41 LFI economies in our sample. The former essentially constitute the group of "emerging markets" and account for a substantial fraction of net capital flows from industrial to developing countries in recent decades. ${ }^{9}$ The group of industrial countries corresponds to a sub-sample of the OECD economies for which data used in the empirical analysis are available.

In our regressions, we use two measures of trade integration. The first measure is a binary one borrowed from Sachs and Warner (1995), who measure openness based on the extent of restrictiveness of a country's trade policies. ${ }^{10}$ The second measure is a continuous one used widely in the literature--the ratio of imports and exports to GDP. Similarly, we employ both a

\footnotetext{
${ }^{9}$ This classification results in a set of MFI economies that roughly correspond to those included in the MSCI emerging markets stock index.

${ }^{10}$ The Sachs and Warner measure assumes that a country is closed to trade in a particular year if it has one of the following features: (1) average tariff rates of 40 percent or more; (2) nontariff barriers covering 40 percent or more of trade; (3) a black market exchange rate that is depreciated by 20 percent or more relative to the official exchange rate, on average, during the 1970 s or 1980s; (4) a state monopoly on major exports; or (5) a socialist economic system. We also use the openness data in Wacziarg and Welch (2003), who extend the Sachs-Warner study.
} 
binary and a continuous measure of financial integration. Our binary measure takes a value of one when the equity market is officially liberalized; otherwise, it takes a value of zero. The majority of the dates of official financial liberalization for individual countries are taken from Bekaert, Harvey, and Lundblad (2002a) and Kaminsky and Schmukler (2002). ${ }^{11}$ The former set of authors document a chronology of official liberalizations of stock markets based on the dates of regulatory changes and the dates on which foreigners were granted access to the local market. The latter provide a chronology of financial liberalizations based on the dates of deregulation of the capital account, the domestic financial sector, and the stock market. Our second financial integration measure - the ratio of gross capital flows to GDP--is analogous to the trade openness ratio. A detailed description of the dataset and sources are provided in Appendix A. Appendix B includes a list of liberalization dates for the MFI economies in the dataset.

Our binary indicators can be considered as measures of de jure trade and financial integration while the continuous measures capture de facto integration. ${ }^{12}$ The distinction between de jure and de facto measures is of particular importance in understanding the effects of financial integration since many economies that have maintained controls on capital account transactions have found them ineffective in many circumstances, particularly in the context of episodes of capital flight. ${ }^{13}$

\section{Growing Global Linkages}

This section documents some empirical evidence about the impressive growth of trade and financial linkages across national economies over the past four decades. The timing of the intensification of these linkages has important implications for our analysis. There has been a

${ }^{11}$ Since these dates are not available on a consistent basis for some countries in our sample, we use various IMF sources to complete the dates of liberalizations. We also experiment with other binary measures of trade and financial integration which are associated with trade and capital account restrictions. These include payment restrictions for current and capital account, export surrender requirements, and multiple exchange rates. The use of alternative binary measures does not affect our main findings.

${ }^{12}$ For the panel regressions, the binary measures are averaged over each decade for each country and can, therefore, take values between 0 and 1 .

${ }^{13}$ See Prasad, Rogoff, Wei and Kose (2003) for a discussion of the relationship between these two concepts of financial integration and the implications of measuring them separately. That paper also provides a more detailed discussion of the sources and construction of the financial openness measures used here. 
substantial increase in the volumes of international trade and financial flows since the mid1980s. For example, private capital flows from industrialized economies to developing economies have increased dramatically since the mid-1980s (Figures 2a and 2b). The bulk of this increase has gone to the MFI economies. The main increase in gross capital flows to developing countries has been in terms of FDI and portfolio flows, while the relative importance of bank lending and other official flows has declined over time. ${ }^{14}$

The volume of international trade has also registered a dramatic increase over the last three decades (Figure 2c). For example, Kose, Prasad, and Terrones (2004) report that the average growth rate of trade, measured by the sum of exports and imports, has been more than two times larger than that of GDP in the groups of industrial and MFI countries during the period 1986-1999. Reductions in trade barriers and declines in transport and communications costs have played important roles in driving the rapid growth in trade. In particular, developing countries reduced average tariff rates from around 30 percent in the 1980 s to about 18 percent in the late 1990s. Both developed and developing countries intensified their efforts to liberalize external trade regimes and the number of preferential trade agreements increased from 28 in 1986 to 181 in 2002.

A number of countries have undertaken trade and financial liberalization programs since the mid-1980s. To understand the impact of these programs, we first identify the country-specific dates of trade and financial liberalizations. Most of the dates for trade liberalization are taken from Wacziarg and Welch (2003), who extend the work of Sachs and Warner (1995). In these studies, the dates of trade liberalizations are determined using various country case studies as well as a set of indices based on changes in countries' trade-related policies. As discussed in section II, the majority of the dates of financial liberalizations are from Bekaert, Harvey, and Lundblad (2001) and Kaminsky and Schmukler (2002).

Figures $3 \mathrm{a}$ and $3 \mathrm{~b}$ display the shares of MFI countries in our sample that have undertaken trade and financial liberalization programs over the last two decades, based on the liberalization dates constructed as described above. By 1985, roughly 30 percent of the countries in our sample

\footnotetext{
${ }^{14}$ See Lane and Milesi-Ferretti $(2001,2003)$ for a detailed analysis of the increase in global financial flows. Heathcote and Perri (2004) document that U.S. holdings of foreign assets have grown significantly since the mid-1980s, rising from 8 percent in 1986 to roughly 35 percent of the total U.S. capital stock in 1999.
} 
had liberalized their trade regimes; by 2003, this share had risen to almost 85 percent. The share of countries with open financial accounts rose from 20 percent to about 55 percent over this period.

This section has provided ample evidence that the extent of the increase in international trade and financial linkages since 1985 has been quite remarkable. As we noted in the previous section, the RR results about the relationship between growth and volatility are based on a dataset that ends in 1985. In addition to studying the impact of a broader set of controls on the basic RR finding, the recent empirical literature building on the RR paper has examined whether the negative relationship between growth and volatility is still valid when data for the post-1986 period are included. While these are important contributions, we argue that it is critical to account for the impact of the remarkable increase in trade and financial linkages during this period on the dynamics of the growth-volatility relationship.

\section{Dynamics of Growth and Volatility}

This section first discusses some stylized facts about the evolution of growth and volatility over time and across different groups of countries. A brief descriptive analysis of the dynamics of growth and volatility before and after financial and trade liberalizations is then provided.

\section{V.1. Evolution of Growth and Volatility}

The first column of Table 1 presents, for different country groupings, the cross-sectional medians of the level and volatility of the growth rates of output and its main components over the past four decades. Volatility is measured by the standard deviation of the growth rate of each variable. ${ }^{15}$ Over the full sample period, output growth is highest on average for industrial countries, followed by MFI economies and then the LFI economies. The order is reversed for output volatility. Thus, at a very coarse level, one can already see evidence of a negative crosssectional relationship between growth and volatility.

\footnotetext{
15 The use of alternative volatility measures such as the coefficient of variation is complicated by the fact that the sample contains countries that have average growth rates that are near zero in some decades.
} 
This is confirmed by a cross-sectional plot of growth against volatility (Figure 4a). In effect, this is the updated version of the basic RR regression. The relationship is, however, different across the three groups of countries. Like Ramey and Ramey, we find a positive relationship between growth and volatility among industrial countries and a negative one among developing countries (Figures $4 \mathrm{~b}$ and $4 \mathrm{c}$ ). But the relationship also differs among the developing countries. While it is strongly negative for LFI economies, it is positive among the group of MFI economies (Figures 5a and 5b). These results suggest the need to clearly discriminate among these different groups of countries in further analysis.

Next, we provide some basic stylized facts from a time-series perspective. An examination of changes in patterns of macroeconomic volatility over time (columns 2-5 of Table 1) reveals that average output growth and volatility have both been declining in industrialized countries over the past two decades. ${ }^{16}$ Both MFI and LFI economies saw a decline in their average output growth rates in the 1980s and a subsequent rebound in the 1990s, although growth remained below the corresponding levels in the 1970s. The evolution of volatility is less similar across these two groups, with MFI economies experiencing a small increase in volatility in the 1980s while LFI economies had a significant decline in their volatility in each of the last two decades. From this very broad perspective, it is difficult to detect a stable time-series relationship between growth and volatility that is consistent across the different groups of countries.

The results for the levels and volatility of consumption growth, reported in the second panel of Table 1, show a similar pattern in the sense that industrialized countries have the highest average consumption growth rate, followed by MFI and LFI economies; for the volatility of consumption growth, the order is reversed. However, while both industrialized and LFI countries witness a decline in the volatility of consumption growth in the 1990s, MFI economies show no such improvement. This suggests that MFI economies do not appear to be benefiting from

\footnotetext{
${ }^{16}$ It has been extensively documented that there has been a steady decline in the volatility of macroeconomic aggregates of industrialized countries since the 1970s (Stock and Watson (2002), and Kose, Prasad, and Terrones (2004)).
} 
financial integration in terms of using access to international capital markets to better share risk and smooth consumption growth. ${ }^{17}$

The results for investment are also different than those for output in some respects. For example, one key difference is that average investment growth for industrial economies picks up significantly in the 1980s after dipping sharply in the 1970s, and then settles back slightly in the 1990s. For both groups of developing economies, average investment growth slows down in the 1980 s before rebounding in the 1990s. Interestingly, while the volatility of investment growth declines slightly in the 1980s and 1990s for both industrial and LFI economies, it rises gradually but noticeably for the MFI economies.

In the case of exports and imports, the basic growth-volatility relationship is preserved over the full sample period across the three groups of countries. On average, industrial counties display the highest level of growth and lowest volatility, with MFI and LFI economies following in the usual order. However, the patterns of growth and volatility across decades again reveal some differences. During the 1990s, MFI countries become the group with the highest levels and volatility of import growth rates. Again, the relationship between growth and volatility of these macroeconomic variables has been changing over time even within country groups, implying that no clear pattern emerges from this analysis.

In order to examine whether the results discussed above could be distorted by the use of decade averages, we plot the growth and volatility of each variable for different groups of countries using ten-year rolling windows for both the growth and volatility measures (Figures 6a and $6 b)$. The qualitative features of the results in Table 1 are generally preserved, indicating that the use of decade averages is not driving or distorting either the cross-sectional or time-series results.

\section{V.2. Growth and Volatility: Before and After Liberalizations}

A different approach to exploring the effects of globalization on the growth-volatility relationship is to examine if it has shifted during the period of globalization. As a first cut, we

\footnotetext{
${ }^{17}$ Kose, Prasad, and Terrones (2003b) find that cross-country consumption correlations have not increased in the 1990s, precisely when financial integration would have been expected to result in better risk-sharing opportunities, especially for developing countries.
} 
split the sample into two periods-1960-85 and 1986-2000 (Figure 7). We picked this break point since, as noted earlier, capital flows across industrial countries as well as between industrial and developing countries surged dramatically starting in the mid-1980s. The results do not show a sharp shift in the relationship across the two periods. For industrial economies, the relationship is strongly positive in both periods. For developing economies, it becomes more strongly negative in the second period. One potential problem with these figures is that, since trade and financial liberalization occurred at different times especially among the developing economies, the choice of an identical break-point in the sample for all countries could be distorting the results.

To overcome this problem, we turn our attention to the group of MFI economies, which faced the most dramatic shifts in openness to trade and financial flows during the past twenty years. For example, 20 out of $23 \mathrm{MFI}$ economies in our sample implemented trade and/or financial liberalization reforms after 1985. In addition, anecdotal evidence suggests that these economies faced the largest shift in the growth-volatility relationship during the 1990s as periods of high growth were followed by periods of severe financial crises in some MFI economies.

Figures $8 \mathrm{a}-8 \mathrm{~b}$ show the relationship for this group of economies before and after trade and financial liberalization, respectively. The results indicate a major change in the growthvolatility relationship after liberalizations. For example, the relationship is strongly negative in the period before trade liberalization and positive after that. The difference between the pre- and post-financial liberalizations periods follows a similar, but a somewhat less striking pattern. These suggest that trade and financial integration might have a considerable effect on how volatility and growth are associated.

To explore this finding further, we conduct an event study analysis for the MFI economies and examine the dynamics of growth and volatility before and after the different measures of liberalization. Table 2 presents the cross-sectional mean and median values of average levels and volatility of growth for the MFI sample before and after trade and financial liberalizations. There is a sharp increase in the average growth rates of output and its components after trade liberalizations. Financial liberalizations also are, on average, associated with improvements in the growth performance of the MFI economies. Figures 9a-9b show that these results are not just driven by a small set of countries. For most of the countries in our sample, average growth rates of output increase after trade liberalization. The results are similar, but a bit 
weaker, for financial liberalization. The lower panel of Table 2 indicates that there is only a modest reduction in the average volatility of output growth after trade or financial liberalizations, a result that is echoed by the country-specific results in Figures 10a-10b. Table 2 indicates that a similar result holds for the volatility of consumption growth. Interestingly, however, the volatility of the growth rates of the other components of output do appear to decline significantly after trade or financial liberalizations.

We now turn to a more detailed study of the time profiles of growth and volatility before and after liberalizations. We first compute the level and standard deviation of average growth rates of output, consumption, investment, exports, and imports for each MFI economy over an eight-year rolling window. ${ }^{18}$ We then examine the behavior of sample median volatility and growth over this window before and after the date of liberalization.

Figures 11a-11b display the evolutions of the cross-sectional medians of average growth rates of output and its components for eight years before and eight years after a trade liberalization event. It appears that trade liberalizations often take place around the time of an economic slowdown and are in general followed by a substantial expansion in economic activity in the succeeding eight-year period. Changes in the growth rate of consumption closely follow those in output. After a trade liberalization, investment growth on average rises more than output growth, implying a substantial increase in the rate of investment (investment/output). On average, the growth rates of imports and exports also register noticeable increases following a trade liberalization.

Figures 11c-11d show the median growth rates before and after a financial liberalization. Financial liberalization programs are also associated with a pickup in output growth, but the increase in the cross-sectional average of output growth rates is smaller than in the case of trade liberalizations. After financial liberalizations, there is typically also a substantial increase in the growth rates of investment and imports.

How can we explain the V-shaped behavior of the growth performance of MFI countries before and after a liberalization? First, most of the liberalization programs were probably

\footnotetext{
${ }^{18}$ Since some of these countries undertook liberalizations only during the 1990s, we kept the span of the rolling window at eight years in order to better capture differences before and after these events. Using a ten year rolling-window did not lead to any significant changes in our findings.
} 
undertaken following an economic slowdown or crisis. Indeed, Tornell (1998) argues that economic reforms generally take place in the aftermath of economic and/or political crises and documents that, between 1970 and 1995, almost 60 percent of trade liberalizations were implemented during periods of economic turmoil. Second, implementation of liberalization programs could signal a change in the nature of economic policies, which in turn leads to increased credibility. In the case of financial liberalization, this probably increases both foreign financial flows and domestic investment, which results in an increase in economic growth. In the case of trade liberalization, there could be an increase in domestic investment growth because of the fall in the cost of foreign capital goods and intermediate inputs. The export sector would also be expected to expand faster following a trade liberalization due to increased access to foreign markets. Both of these could boost output growth in the aftermath of trade liberalization programs.

Figures 12a-12d display how the cross-sectional medians of the volatility of the growth rates of output and its components evolve before and after trade and financial liberalizations, respectively. Neither type of liberalizations leads to a major change in the volatility of output growth. While growth rates of investment, exports, and imports become less volatile after trade and financial liberalizations, there is no discernible change in the volatility of consumption growth.

Some of our results are consistent with the findings documented in the existing literature. For example, Wacziarg and Welch (2003) examine the growth performance of a large set of developed and developing economies twenty years before and twenty years after a trade liberalization. They document that trade liberalizations are associated with an increase in the average growth rate of output and an increase in the investment rate. Bekaert, Harvey, and Lundblad (2001) find that equity market liberalizations on average produce a one percent increase in the growth rate of output over a five year period and lead to an increase in the investment rate. However, in the case of the impact of financial liberalizations on volatility, our results are somewhat different than those of Bekaert, Harvey, and Lundblad (2002), who employ a larger sample of countries than in our dataset. They find that, after equity market liberalizations, there is generally a significant decrease in the volatility of output and consumption growth. 
The descriptive analysis in this section was intended to motivate and set the stage for the next phase of the empirical work by displaying the unconditional relationship between volatility and growth from various angles. While the analysis indicates that this relationship has been changing over time and across different country groups in response to increased trade and financial flows, it is unable to account for some important considerations. First, the coarse country grouping used in the descriptive analysis so far does not capture differences in and changes over time in the degree of trade and financial integration of different countries. Second, this is a static classification of countries, which is unable to take into consideration other country characteristics that could influence both growth and volatility. Moreover, trade and financial liberalization programs are often accompanied by other reforms and policy measures that could have an impact on the relationship between growth and volatility. To address these issues, we now turn to a more formal regression analysis of this relationship.

\section{Understanding the Effects of Integration on the Growth-Volatility Relationship}

We now undertake a more formal analysis of the relationship between growth and volatility using a variety of regressions. In order to examine the impact of integration on this relationship, we take a simple approach of interacting volatility with the measures of integration in our regressions. We first study the cross-sectional relationship and then use panel regressions to exploit the information associated with the cross-section as well as time series dimensions of our database. Next, we study the impact of different types of financial flows on the growthvolatility relationship. In particular, we focus on FDI flows and other types of capital flows, which include portfolio equity flows, portfolio bond flows, and bank lending. We then examine the potential impact of various additional control variables - such as the ratio of credit to GDP, the investment rate, financial development, and institutional quality — on our basic results This section is followed by a series of robustness tests of our main results. These tests involve fixed effects, least absolute deviation, and instrumental variables regressions.

\section{VI.1 Cross-Section Analysis}

\section{The basic relationship between growth and volatility}

We begin by examining the cross-sectional relationship between output growth, measured as the average growth rate of per capita GDP, and volatility, measured as the standard 
deviation of output growth. The first regression that Ramey and Ramey (1995) report in their paper is a cross-sectional regression of mean output growth on the standard deviation of output growth for a 92-country sample over the period 1962-85. They report that the coefficient on output volatility is significantly negative. We re-estimate the basic RR regression with our sample of 85 countries for the period 1960-2000. As shown in Table 3, we get a statistically significant coefficient of -0.23 (column 1), confirming that the basic RR result is preserved in our sample.

We then examine this relationship within different country groups. A similar regression based on our subsample of 21 industrial countries yields a significantly positive coefficient of 0.42 (column 2). RR find that, in their sample of 24 OECD economies, the coefficient on volatility is positive, but not significantly different from zero. One potential explanation of the difference between these two results is that the positive association between volatility and economic growth among industrial countries might have become stronger over time. ${ }^{19}$

In the case of the developing country subsample, we find a negative and statistically significant relationship between growth and volatility (column 3). We then analyze how the growth-volatility relationship differs across industrial, MFI and LFI countries. To do this, we interact volatility with dummies for the three groups of countries. We again find a statistically significant positive relationship between volatility and growth for industrial countries (column 4). The results suggest that there is a weak positive association between volatility and growth (borderline significant at the 10 percent level) for MFI countries, whereas it is negative (but not statistically significant) for LFI countries. In addition, the coefficient associated with LFI countries appears to be different than those of other countries.

There are three main results we take from this exercise. First, the unconditional relationship between growth and volatility documented by RR is preserved in our sample, suggesting that countries with higher volatility in growth rates tend to display lower average growth. Second, the basic relationship is sensitive to the choice of country groups. In particular, the results indicate that, while there is a significant positive relationship for industrial countries, the relationship is significantly negative for developing countries. Third, the association between

\footnotetext{
${ }^{19}$ Other reasons could be the difference in sample coverage ( 21 industrial countries in ours versus 24 in theirs) and data revisions in the PWT.
} 
growth and volatility appears to differ across the groups of MFI and LFI economies. The latter two results suggest that levels of trade and financial integration might have an influence on the growth-volatility relationship.

\section{Additional growth controls and the basic relationship}

However, these bivariate regressions set aside the issue of additional controls that could explain growth. For this, we draw upon the growth literature and include a set of standard controls including the log level of initial per capita income and the fraction of the population that has attained a secondary education. ${ }^{20}$

We present the results of regressions with additional controls in Table 4 (column 2). The results indicate that additional controls are statistically significant with their expected signs as secondary education, which is a measure of investment in human capital, has a significantly positive impact on growth and initial per capita income has a significant and negative impact, which has been interpreted as evidence of conditional convergence. However, the coefficient on volatility now becomes smaller and loses its statistical significance. ${ }^{21}$

At this juncture, we are left with two possibilities. One is that the growth-volatility relationship is a fragile one, and volatility has little measurable impact on growth once other country characteristics are accounted for. Another possibility is that, as suggested by some other studies in the literature, the growth-volatility relationship is more subtle than can be captured by a simple linear specification. For instance, the RR result that the unconditional correlation between volatility and growth is negative for developing countries and positive for industrial countries would generate a type of nonlinearity. Our findings in Table 3 also indicate that there

\footnotetext{
${ }^{20} \mathrm{We}$ also experimented with numerous other controls, but found that, of the core set of determinants identified in the literature on growth regressions, only these two seemed to matter in most of the regressions reported in this paper once we included measures of integration and volatility. The RR study includes the following additional controls: the share of investment in GDP and the average growth rate of the population. In our robustness tests (reported later in the paper), we find that inclusion of these variables does not affect any of our findings.

${ }^{21}$ This result is consistent with the findings of Fatas and Mihov (2004), whose dataset comprises annual data over the period 1960-2000 for 74 countries. In addition to the controls used here, they include primary education in their regressions. While the unconditional growth-volatility relationship is significantly negative in their sample, it becomes insignificant when they introduce the additional growth controls.
} 
could be such a nonlinear relationship between growth and volatility. In a similar vein, Fatas (2003) finds that, for countries with high levels of per capita GDP, the relationship between growth and volatility turns positive. We now pursue this second possibility but, instead of simply linking the nonlinearity to just a country's stage of development, we specifically examine whether trade and financial linkages have any impact on this relationship. ${ }^{22}$

\section{The roles of trade and financial integration}

We now add different measures of integration to the cross-section regression to analyze how individual aspects of globalization affect the growth-volatility relationship. When we introduce the measures of trade integration, both measures are statistically significant and positive, indicating that trade integration has a positive impact on economic growth, after controlling the effect of volatility (column 3).

We interact volatility with the integration variables to examine if the relationship between growth and volatility is linked to the degree of integration. When we interact the volatility variable with measures of integration, we always use continuous rather than discrete measures of the latter. For trade integration, we use the standard measure of openness, i.e., the ratio of the sum of exports and imports to GDP. For financial integration, we use the de facto measure of integration based on the gross flows of foreign assets and liabilities as a ratio to GDP. These continuous measures capture variations over time in the degree of trade and financial integration better than the binary ones as they more accurately reflect the changes in annual trade and financial flows.

Column 4 of Table 4 shows that the interaction between volatility and trade integration is significantly positive. The coefficient on volatility is also now significant and negative. The positive interaction term indicates that, the greater the degree of trade integration, the weaker the tradeoff between volatility and growth. In other words, for a given level of volatility, economies with a higher degree of trade integration appear to suffer smaller negative effects on growth than those with a lower degree of trade integration. Column 5 reports results for the measures of financial integration. The basic relationship between growth and volatility again disappears and

\footnotetext{
${ }^{22} \mathrm{We}$ find that the coefficient is statistically significant and negative when we re-estimate our basic regressions after controlling potential endogeneity in the relationship between volatility and growth using instrumental variables.
} 
only the binary measure of financial integration has a positive and statistically significant coefficient. When we interact financial integration with volatility, we find that the coefficient on the interaction variable is also positive and statistically significant (column 6). Thus, as in the case of trade integration, a higher degree of financial integration appears to attenuate the negative growth-volatility relationship in the cross-section.

We now turn our attention to the roles played by trade and financial integration together to get a better grasp of how different aspects of globalization affect the relationship between growth and volatility. When we introduce the simple binary measures of trade and financial integration together, we find that trade integration has a strongly positive coefficient while financial integration does not have a significant effect (column 7). We then interact volatility with the standard trade integration measure. The coefficient on the interaction term is again significant and positive and, moreover, the coefficient on volatility becomes bigger in absolute value (column 8). When we interact volatility with financial openness, we find that the coefficient on the interaction term is positive, but neither the coefficient on the interaction term nor the one on volatility is statistically significant (column 9).

When we include both the trade and financial interaction terms, the positive coefficient on the interaction with trade integration stays statistically significant, while the coefficient on the financial integration interaction tern turns negative and significant (column 10). One interpretation of this result is that higher trade openness clearly brings with it benefits in terms of higher growth even though it may also expose an economy to more volatility arising from external shocks. This is consistent with a large body of literature showing that trade integration is good for growth (Berg and Krueger, 2003) but is typically associated with higher volatility (Kose, Prasad and Terrones, 2003a).

On the other hand, once one accounts for trade integration, financial integration appears to have a negative impact on the growth-volatility tradeoff. Does this result imply that the adverse impact of macroeconomic volatility is further exacerbated in more financially integrated economies? Such a strong conclusion, however, may not be warranted simply based on the crosssection regressions, which do not utilize the marked variation over time in the measures of integration. As we documented in section IV, trade linkages have increased substantially over the last four decades. Moreover, these changes over time are particularly important in the context of financial integration that has been greatly accentuated since the mid-1980s. Hence, we now turn 
to a panel analysis of the relationship between volatility and growth to capture the role of temporal changes in trade and financial flows.

\section{VI.2 Panel Analysis}

For this part of the analysis, we break the dataset into four separate decades. ${ }^{23}$ This means that, for each country, we have a maximum of four observations. For some countries, we were unable to get data on the financial openness variable for the 1960s, so we lose a few observations in that decade. We use average growth rates and the standard deviation of growth over each decade of the sample and corresponding transformations for the other variables in the regressions. ${ }^{24}$ For initial conditions such as the level of initial per capita income, we use the data at the beginning of each decade. All of the panel regressions below include time effects (dummies for three of the four decades).

The first column of Table 5 shows that, in the panel, the correlation between volatility and growth is very similar to that in the cross section (cf Table 3, column 1). As in the crosssection regressions, the coefficient remains negative and statistically significant but becomes smaller in absolute value. While the panel OLS regressions also suggest that there is a positive association between growth and volatility for industrial countries and a negative one for developing countries, these coefficients are not statistically significant (columns 2 and 3 ). However, when we interact volatility with country group dummies, we find that all of the coefficients have the same signs as in our cross-section regressions and the coefficients of volatility interacted with industrial and LFI country dummies become significant (column 4). These findings also point to the existence of a nonlinearity in the growth-volatility relationship.

The results in Table 6 suggest that, as in the cross-section regressions, the coefficient on volatility remains negative but statistically insignificant when our core set of controls for growth are introduced into the basic panel regression framework (column 2). Columns 4 and 6 indicate

${ }^{23}$ There is, of course, nothing sacrosanct about using decades rather than other breakdowns of the full sample into sub-periods. In ongoing work, we are examining the sensitivity of our results to different sub-period lengths (e.g., non-overlapping 8-year windows) and the use of rolling 10year windows of the data.

${ }^{24}$ For the panel regressions, the binary measures are averaged over each decade for each country and can, therefore, take values between 0 and 1 . 
that, when the trade integration and financial integration measures are interacted with volatility separately, the interaction terms are significantly positive. Columns 8 and 9 present different specifications confirming that both trade and financial integration significantly reduce the adverse impact of volatility on growth. Our main finding is that, when the effects of trade and financial integration are studied together in panel regressions, the results are stronger (column 10). Both of the interaction terms are significantly positive, suggesting that both trade and financial integration attenuate the negative relationship between growth and volatility.

These findings indicate that, when we take into account the information associated with the time-series dimension of our database, more financially integrated economies also have a less severe growth-volatility tradeoff, even after controlling for trade integration. This result has some intuitive appeal in terms of relating it to the experiences of emerging markets that, during the late 1980s and 1990s, experienced relatively high growth but also higher volatility. In addition, it ties in nicely with the basic RR result that, among industrial economies, which tend to be more open to financial flows, the relationship between growth and volatility is positive. Moreover, this finding is also compatible with our results in Table 5, which suggest that the basic growth-volatility relationship is significantly positive for MFI countries while it is significantly negative for the group of LFI economies.

Our result about the effects of trade integration is consistent with several recent studies documenting the positive impact of trade integration on growth and a related literature suggesting that economies that are more open to trade tend to be more vulnerable to external shocks. Our finding that the coefficient associated with the financial integration interaction term is of a similar sign but less robustly significant than that for trade integration could also be interpreted in light of another body of literature. It is consistent with some recent studies (discussed earlier) showing that the direct causal effects of financial integration on growth are not strongly and robustly positive but that its effects on volatility are more apparent (Prasad, Rogoff, Wei and Kose, 2003).

\section{VI.3 Different Types of Financial Flows}

As discussed in section II, some studies find that different types of financial flows may have different effects on economic performance. In particular, these studies consistently indicate that FDI flows tend to be positively associated with growth rates of domestic investment and 
output. While other forms of capital inflows could also have a positive association with economic growth, their impact tends to be smaller and less robust. ${ }^{25}$ Another important feature that has been documented in the literature is that different types of capital flows differ substantially in terms of their volatility. For example, FDI flows constitute the least volatile category of financial flows to developing countries, which is not surprising given their long-term and relatively fixed nature. Portfolio flows tend to be far more volatile and prone to abrupt reversals (Wei (2001)).

To further analyze the impact of financial integration on the growth-volatility relationship, we now turn our attention to a comparison of the impacts of different types of financial flows. We focus on two broad categories--FDI flows and all other categories of flows, including portfolio equity flows, portfolio bond flows, and bank lending. The results of crosssection and panel regressions are presented in Tables 7 and 8, respectively.

Columns 1-4 of Table 7 present the results of cross-section regressions when volatility is interacted with financial integration, now measured by the ratio of gross flows of FDI to GDP. The coefficients associated with the interaction terms suggest that FDI flows have a significant positive impact on the relationship between growth and volatility (columns 2, 3, and 4). However, when volatility is interacted with the other financial integration measure, which is based on all non-FDI inflows and outflows as a ratio of GDP, the interaction term on financial integration is positive in column 6 but not statistically significant, and it turns negative in column 7 when the binary measure of trade openness is introduced. Moreover, when the trade openness interaction is included, this coefficient turns significantly negative (column 8). In other words, the results from the cross-section regressions suggest that FDI flows dampen the adverse impact of volatility on economic growth, while portfolio and other flows tend to intensify the negative relationship between volatility and growth.

The results of the corresponding panel regressions in Table 8 suggest that FDI flows have a statistically significant impact on the growth-volatility relationship when the regressions include only the financial integration interaction with volatility (columns 2 and 3 ). When both trade and financial integration and their interactions with volatility are introduced into the panel

\footnotetext{
${ }^{25}$ See Reisen and Soto (2001) for an extensive discussion about the relative benefits of different types of financial flows.
} 
regressions, the coefficient on the interaction of FDI flows with volatility still has a positive sign, but it becomes insignificant (column 4). In the case of other financial flows, the panel regressions, in contrast to the cross-section results, suggest that these flows reduce the adverse impact of volatility on growth (columns 7 and 8).

Our findings emphasize the importance of both FDI flows and other types of financial flows in driving the empirical link between growth and volatility. As we discuss in detail in our concluding comments, these results suggest that a deeper investigation of different types of flows on the growth-volatility relationship is warranted in further work. Irrespective of the measure of financial integration, the interaction term with trade integration is always statistically significant and positive in our cross-section and panel regressions in Tables 7 and 8.

\section{Robustness of the Results}

Our main result is that trade and financial integration appear to attenuate the negative growth-volatility relationship. While the role of trade integration in dampening the adverse impact of volatility on growth is significant and robust, the role of financial integration is often significant but tends to be less robust. In this section, we examine the overall robustness of our main results. We first study the impact of other control variables that represent various channels linking volatility to growth. We then consider alternative regression frameworks to take into account some potential misspecification problems, which could be associated with our earlier regressions.

\section{VII.1 Other Control Variables}

As discussed in section II, several studies argue that the empirical link between volatility and economic growth is based on the dynamics of investment. To examine the role of the investment channel, we introduce the investment rate (ratio of investment to output) in our regressions. For comparison purposes, we present our main findings in Column 1. Column 2 of Table 9 shows that the investment rate has a statistically significant and positive effect on growth. Moreover, after taking into account the role of investment, the coefficient on volatility becomes smaller in absolute value, but its statistical significance is preserved. The inclusion of the investment ratio does not affect our main findings. Both the trade and financial openness 
interaction terms are still significant, albeit smaller in absolute size than in our main specification.

Another important channel linking volatility to growth is financial market development. We measure the level of financial market development with a couple of measures. The first one is the ratio of broad money to GDP (M2/GDP). The second is the ratio of total credit to private sector to GDP. Neither of these measures turns out to be statistically significant (columns 3 and 4). We then interact the credit rate with volatility to analyze whether the growth-volatility tradeoff becomes less severe in countries with more developed financial markets. The interaction term is positive and significant, suggesting that the level of development of domestic financial markets is also critical in determining the empirical link between growth and volatility (columns 5 and 6). However, the interaction terms associated with trade and financial integration are still statistically significant and positive. This suggests that the impact of trade and financial integration on the growth-volatility relationship is above and beyond the role played by the depth of domestic financial markets. ${ }^{26}$

Some recent studies argue that the quality of institutions play an important role in determining the dynamics of growth and of volatility. We introduce various measures of institutional quality into our regressions to assess the robustness of our findings to this common factor that may affect both growth and volatility. For example, we experiment with measures of property rights, which indicates the degree of legal protection given to the ownership of private property; constraints on the executive branch of government, reflecting institutional and other limits placed on presidents and other political leaders; and political stability, which captures the likelihood that the government will be overthrown by unconstitutional or violent means. However, none of these measures of institutional quality turns out to be significant (columns 8 , $9,10)$ or has a major impact on our key results. ${ }^{27}$ The results of this section suggest that our findings are robust to the introduction of other major control variables.

\footnotetext{
${ }^{26}$ Another control used by RR is the average population growth rate. When we introduce this variable in the regression (column 7), its coefficient is not significant and our main results do not change.

${ }^{27}$ We also try other variables, including legal origins, which capture a country's legal origin, and ethnolinguistic diversity, indicating the probability that two randomly selected individuals from a country are from different ethnolinguistic groups. The results do not change.
} 


\section{VII.2 Alternative Regression Frameworks}

We first analyze the results from regressions with fixed effects (FE). FE regressions help account for country-specific characteristics that may not be captured by the explanatory variables in our models. Columns 2-5 of Table 10 present the results of FE regressions. These results are encouraging in the sense that they are consistent with our main findings, which are presented in Column 1: the interaction terms on both trade and financial integration are statistically significant and positive.

Another potential problem associated with our results is that they could be driven by outliers. To check this, we re-estimate our main specification using least absolute deviation (LAD) regressions, which use the median as a measure of central tendency. The interaction term on trade integration is still statistically significant while the one on financial integration becomes insignificant in LAD regressions (column 6). In other words, trade integration once again has a robust impact on the growth-volatility relationship while financial integration appears to play a less important role.

Finally, we focus on problems associated with the potential endogeneity of volatility and the measures of integration. We re-estimate our main specification using an instrumental variables (IV) approach. ${ }^{28}$ The results suggest that the interaction term on trade integration is significantly positive while the coefficient associated with financial integration interaction turns insignificant (Column 7). These findings indicate that the main findings our paper are reasonably robust to potential concerns about misspecification associated with fixed effects, the presence of outliers, and endogeneity of regressors. However, as noted earlier, while the role of trade integration in dampening the adverse impact of volatility on growth is significant across all these robustness tests, the role of financial integration tends to be less robust and becomes insignificant in some instances.

\footnotetext{
${ }^{28}$ We use a broad set of instruments for volatility and integration measures. In particular, our instruments include volatility of tot, volatility of the annual change in trade openness ratio, volatility of the annual change in non-FDI flows ratio, volatility of the annual change in FDI flows ratio, the initial value of M2/GDP in each decade, the ratio rural population to total population, and a dummy for multiple exchange rate arrangements. The average of the R-squares from the first-stage IV regressions is equal to 0.44 .
} 


\section{Conclusions and Possible Extensions}

To summarize, we document that the negative relationship between volatility and growth has survived into the 1990s, but with some important qualifications. Our main finding is that trade and financial integration appear to attenuate the negative growth-volatility relationship. Specifically, we find that the estimated coefficients on interactions between volatility and trade integration are significantly positive suggesting that countries that are more open to trade appear to face a less severe tradeoff between growth and volatility. We find a similar, although less significant, result for the interaction of financial integration with volatility. Thus, both trade and financial globalization appear to give more room for economies to handle volatility without adversely affecting growth.

In future work, we intend to explore in more detail the relationship between growth and the volatility of the components of output — in particular, consumption and investment. This enables us to relate our results to two strands of theoretical work. The first links overall macroeconomic volatility to investment growth and, by extension, to output growth. The second is related to how the volatility of consumption growth reflects the availability of consumption smoothing opportunities that could divorce the growth of output from its volatility. This is of particular importance in understanding the welfare implications of volatility because, ultimately, it is the growth and volatility of consumption rather than output that matter for welfare. Another important issue we would like to analyze further is the impact of different types of financial flows on the volatility-growth relationship. We also plan to examine how capital account openness and domestic financial sector liberalization jointly affect an economy's growth rate and exposure to macroeconomic volatility. 


\section{References}

Acemoglu, Daron, S. Johnson and J. Robinson, 2004, "Institutions as the Fundamental Cause of Long-run Growth”, NBER Working Paper 10481, (Cambridge, Massachusetts: National Bureau of Eocnomic Research).

Acemoglu, Daron, S. Johnson, J. Robinson, and Y. Thaicahroen, 2003, “ Institutional causes, macroeconomic symptoms: volatility, crises and growth", Journal of Monetary Economics, Vol 50, pp 49-123.

Aghion, Philippe, Abhijit Banerjee, and Thomas Piketty, 1999, "Dualism and macroeconomic volatility," Quarterly Journal of Economics 114, pp. 1359-1397.

Aghion, Philippe, Philippe Bacchetta, and A. Banerjee, 2000, Capital markets and the instability in open economies, in P. R. Agenor, M. Miller, D. Vines, and A. Weber (Eds.), The Asian Crisis: Causes, Contagion, and Consequences, Cambridge University Press.

Aizenman, Joshu, and Nancy Marion, 1993, "Policy uncertainty, persistence and growth," Review of International Economics 1, pp. 145-163.

Aizenman, Joshu, and Nancy Marion, 1999, "Volatility and Investment: Interpreting Evidence from Developing Countries”, Economica, Vol 66, pp157-79.

Backus D. K., P. J. Kehoe and F.E. Kydland, 1995, “International business cycles: Theory and Evidence", in C. Plosser ed., Frontiers of Business Cycle Research, Princeton University Press, 331-357.

Baldwin, R., 2003, “Openness and Growth: What Is the Empirical Relationship?” NBER Working Paper 9578, (Cambridge, Massachusetts: National Bureau of Eocnomic Research).

- and E. Seghezza, 1996, “Testing for Trade Induced-Investment Led Growth,” NBER Working Paper 5416, (Cambridge, Massachusetts: National Bureau of Eocnomic Research).

— International Economics Vol. 3, ed. by Gene M. Grossman and Kenneth Rogoff, (Amsterdam: North-Holland), pp. 1597-1644.

Baxter, M., and M. Crucini, 1995, "Business cycles and the asset structure of foreign trade", International Economic Review 36, 821-854.

Bekaert, Geert, Campbell R. Harvey, and Christian Lundblad, 2001, "Emerging Equity Markets and Economic Development," Journal of Development Economics, Vol. 66, pp. 465-504. 
— , 2002a, "Growth Volatility and Equity Market Liberalization,” Working Paper, (Duke University).

— , 2002b, “Does Financial Liberalization Spur Growth?” mimeo, Columbia University.

Berg, A. and A. Krueger, 2003, "Growth and Poverty: A Selective Survey," IMF Working Paper 03/30 (Washington: International Monetary Fund).

Bernanke, Ben, 1983, “Irreversibility, Uncertainty, and Cyclical Investment," Quarterly Journal of Economics, Vol 98, pp 85-106.

Blackburn, Keith, and Alessandra Pelloni, 2002, "Growth, Cycles and Stabilization Policy," Discussion Paper Series No. 012 (UK, Centre for Growth and Business Cycle Research, School of Economic Studies, University of Manchester).

Blackburn, Keith, 1999, “Can Stabilization Policy Reduce Long-run Growth?”, The Economic Journal, Vol 109, pp 67-77.

Borensztein, Eduardo, José De Gregorio, and Jong-Wha Lee, 1998, "How Does Foreign Direct Investment Affect Growth?” Journal of International Economics, Vol. 45 (June), pp. $115-35$.

Buch, C. M., J. Dopke, and C. Pierdzioch, 2002, "Financial openness and business cycle volatility," Working Paper, Kiel Institute for World Economics.

Caballero, Ricardo J., and Arvind Krishnamurthy, 2001, "International and domestic collateral constraints in a model of emerging market crises," Journal of Monetary Economics, Vol. 48, pp. 513-548.

Calvo, Guillermo, Leonardo Leiderman, and Carmen Reinhart, 1998, "Varities of CapitalMarket Crises," IEA Conference Volume, No. 118 (New York: St. Martin’s Press; London: Macmillan Press).

Carlson, Mark A., and Leonardo Hernandez, 2002, "Determinants and Repercussions of the Composition of Capital Inflows," IMF Working Paper 02/86 (Washington: International Monetary Fund).

Catão, Luis, and Sandeep Kapur, 2004, "Missing Link: Volatility and the Debt Intolerance Paradox,” IMF Working Paper 04/51, (Washington: International Monetary Fund).

De Mello, Luiz, 1999, "Foreign Direct Investment-Led Growth: Evidence from Time Series and Panel Date," Oxford Economic Papers, Vol. 51, No. 1 (January), pp. 133-51.

Denizer, C. A., M. F. Iyigun, and A. Owen, 2002, "Finance and macroeconomic volatility", Contributions to Macroeconomics 2, 1-30.

Dollar, David, and Aart Kraay, 2002, "Institutions, trade, and growth," Journal of Monetary Economics, Vol. 50 (2003), pp. 133-162. 
Easterly, William, R. Islam, and Joseph E. Stiglitz, 2001, "Shaken and stirred: explaining growth volatility," Annual World Bank Conference on Development Economics, ed. by B. Pleskovic and N. Stern.

Easterly, William, Ross Levine, and David Roodman, 2003, "New Data, New Doubts: A Comment on Burnside and Dollars "Aid Policies and Growth,"” manuscript.

Easterly, William, and Ross Levine, 2001, "It's Not Factor Accumulation: Stylized Facts and Growth Models,” World Bank Economic Review, Vol. 15, pp. 177-219.

Edison, Hali, Michael Klein, Luca Ricci, and Torsten Sløk, 2002, "Capital Account Liberalization and Economic Performance: A Review of the Literature," IMF Working Paper 02/120 (July), (Washington: International Monetary Fund).

Edison, Hali, Ross Levine, Luca Ricci, and Torsten Sløk, 2002, "International Financial Integration and Economic Growth," Journal of International Monetary and Finance, Vol. 21, pp. 749-76.

Edwards, Sebastian, 2001, "Capital Mobility and Economic Performance: Are Emerging Economies Different?" NBER Working Paper No. 8076 (Cambridge, Massachusetts: National Bureau of Economic Research).

Eichengreen, Barry J., 2001, “Capital Account Liberalization: What do Cross-Country Studies Tell Us?” (unpublished; Berkeley: University of California).

Fatás, Antonio, 2003, “The Effects of Business Cycles on Growth,” manuscript.

— Paper

Frankel, Jeffrey A., and David Romer, 1999, “Does Trade Cause Growth?” The American Economic Review, Vol. 89, No. 3, pp. 379-399.

Gavin, Michael, and Ricardo Hausmann, 1996, "Sources of macroeconomic volatility in developing economies," Working Paper, Inter-American Development Bank.

Gourinchas, Pierre-Olivier, and Olivier Jeanne, 2003, "The Elusive Gains from International Financial Integration,” NBER Working Paper 9684

Grier, Kevin B., and Gordon Tullock, 1989, “An Empirical Analysis of Cross-National Economic Growth, 1951-80,” Journal of Monetary Economics, Vo. 24 (1989), pp. 259276.

Grossman, Gene M., and Elhanan Helpman, 1991, Innovation and Growth in the Global Economy, (Cambridge, Mass. and London: MIT Press).

Henry, Peter, 2000, “Do Stock Market Liberalization Cause Investment Booms?” Journal of Financial Economics, Vol. 58, pp. 301-34. 
Heston, Alan, Robert Summers, and Bettina Aten, 2002, "Penn World Tables Version 6.1," Center for International Comparisons, University of Pennsylvania.

Hnatkovska, Viktoria, and Norman Loayza, November 2003, "Volatility and Growth," manuscript.

Imbs, Jean, 2004, "Why the Link between Volatility and Growth is both Positive and Negative?" London Business School and CEPR.

International Monetary Fund, 2002, World Economic Outlook, September.

Jones, Larry.E, R. E. Manuelli, and E. Stacchetti, 1999, “Technology (and Policy) Shocks in Models of Endogenous Growth", working paper.

Jovanovic, Boyan, 2003, “Asymmetric Cycles”, Working Paper, New York University.

Kalemli-Ozcan, S., B. Sorensen, and O. Yosha, 2003, "Risk Sharing and Industrial Specialization: Regional and International Evidence," American Economic Review, Vol. 93, pp. 903-918.

Kaminsky, G. L. and C. M. Reinhart, 1999, "The twin crises: the causes of banking and balanceof-payments problems", American Economic Review 89, 473-500.

Kaminsky, Graciela and S.L. Schmukler, 2002, "Short-run Pain, Long-run Gain: The effects of financial liberalization”, Working Paper, World Bank.

Karras, G. and F. Song, 1996, "Sources of Business-Cycle Volatility: An Exploratory Study on a Sample of OECD Countries", Journal of Macroeconomics 18, No. 4, 621-637

Klein, Michael, and Giovanni Olivei, 2000, "Capital Account Liberalization, Financial Depth, and Economic Growth" (unpublished; Medford, Mass: Tufts University).

Kose, M. Ayhan, Eswar S. Prasad, and Marco E. Terrones, 2003a, "Financial Integration and Macroeconomic Volatility," IMF Staff Papers (Washington: International Monetary Fund), Vol. 50, pp. 119-42.

— 2003b, "How Does Globalization Affect the Synchronization of Business Cycles?" American Economic Review, Papers and Proceedings, Vol. 93, pp. 57-62.

— 2004, "Volatility and Comovement in a Globalized World Economy: An Exploration", forthcoming, in Horst Siebert ed., Macroeconomic Policies in the World Economy, Springer-Verlag.

Krugman, Paul, 1993, "Lessons of Massachusetts for EMU”, in F. Giavazzi and F. Torres (Eds), "The Transition to Economic and Monetary Union in Europe", Cambridge University Press, pp. 241-261. 
Kroft, Kory, and Huw Lloyd-Ellis, 2002, "Further Cross-Country Evidence on the link Between Growth, Volatility and Business Cycles," manuscript.

Lane, Philip and Gian Maria Milesi-Ferreti, 2001, "The External Wealth of Nations: Estimates of Foreign Assets and Liabilities for Industrial and Developing Countries", Journal of International Economics 55, 263-294.

Lane, Philip and Gian Maria Milesi-Ferreti, 2003, "International Financial Integration,” IMF Staff Papers (Washington: International Monetary Fund), Vol. 50, pp. 82-113.

Levine, Ross, and Sara Zervos, 1998, "Stock Markets, Banks, and Economic Growth," American Economic Review, Vol. 88 (June), pp. 537-58.

—_, and David Renelt, 1992, "A Sensitivity Analysis of Cross-Country Growth Regressions," The American Economic Review, Vol. 82, No. 4, pp. 942-963.

Martin, Philippe, and C.A. Rogers, 2000, "Long-term Growth and Short-term Economic Instability”, European Economic Review, Vol 44, pp359-381.

McConnell, Margaret, and Gabriel Perez-Quiros, 2000, "Output fluctuations in the United States: what has changed since the early 1980s?" American Economic Review Vol. 90, pp. 146476.

Mendoza, E.G., 1994, "The robustness of macroeconomic indicators of capital mobility", in Leonardo Leiderman and Assaf Razin (eds.), "Capital Mobility: The Impact on Consumption, Investment, and Growth”, Cambridge University Press, Cambridge, 83111.

- 1995, "The Terms of Trade, the Real Exchange Rate and Economic Fluctuations," International Economic Review, Vol. 36, pp. 101-137.

— 1997 , “Terms-of-trade uncertainty and economic growth", Journal of Development Economics, Vol 54, pp 323-356.

— 2002, "Credit, prices, and crashes: business cycles with a sudden stop", in Frankel, J., and S. Edwards (Eds.) Preventing Currency Crises in Emerging Markets, University of Chicago Press.

Obstfeld, Maurice, 1998, “The Global Capital Market: Benefactor or Menace?” Journal of Economic Perspectives, Vol. 12 (Fall), pp. 9-30

— No. 8846 (Cambridge, Massachusetts: National Bureau of Economic Research).

Prasad, Eswar S., Kenneth Rogoff, Shang-Jin Wei, and M. Ayhan Kose, 2003, Effects of Financial Globalization on Developing Countries: Some Empirical Evidence, IMF Occasional Paper No. 220 (Washington: International Monetary Fund). 
Rajan, Raguram, and L. Zingales, 1998, "Financial Dependence and Growth, American Economic Review, Vol 88, pp 559-86.

Ramey, Gary, and Valerie A. Ramey, 1995, "Cross-Country Evidence on the Link Between Volatility and Growth," The American Economic Review, Vo. 85, No. 5, pp. 1138-1151

Ranciere, Romain, A. Tornell, and F. Westermann, 2003, "Crises and Growth: A Re-evaluation", NBER Working Paper 10073, (Cambridge, Massachusetts: National Bureau of Economic Research).

Razin, Assaf and Andrew K. Rose, 1994, "Business-cycle volatility and openness: an exploratory cross-sectional analysis", in Leonardo Leiderman and Assaf Razin (eds.), Capital Mobility: The Impact on Consumption, Investment, and Growth.

Reisen, Helmut, and Marcelo Soto, 2001, "Which Types of Capital Inflows Foster DevelopingCountry Growth?," International Finance, Vol. 4, No. 1 (Spring), pp. 1-14.

Rodrik, D. and F. Rodriquez, 2000, "Trade Policy and Economic Growth: A Skeptics Guide to the Cross-National Evidence," in Ben Bernanke and Kenneth Rogoff, eds., NBER Macroeconomics Annual 2000, Cambridge (MA): MIT Press.

Sachs, J., and A. Warner, 1995, "Economic Reform and the Process of Global Integration," Brookings Papers on Economic Activity, Vol. 2, pp. 523-564.

Tornell, Aaron, 1998, “Reform From Within”, NBER Working Paper 6497, (Cambridge, Massachusetts: National Bureau of Economic Research).

Turnovsky, Stephen J., and Pradip Chattopadhyay, 2002, "Volatility and growth in developing economies: some numerical results and empirical evidence," Journal of International Economics, Vol. 59 (2003), pp. 267-295

Wacziarg, Romain, and Karen Horn Welch, 2003, "Trade Liberalization and Growth: New Evidence”, NBER Working Paper 10152, (Cambridge, Massachusetts: National Bureau of Economic Research).

Wei, Shang-Jin, 2001, "Domestic Crony Capitalism and International Fickle Capital: Is there a connection?" International Finance, vol:4, pp.15-46. 


\section{Appendix A}

In this appendix, we list the countries in the sample, along with the country groupings used in the analysis. We also describe the main variables used in the analysis and the main data sources.

The sample comprises 85 countries--21 industrial and 64 developing $^{29}$. The latter are further dividied into 23 More Financially Integrated Economies (MFIs), and 41 Less Financially Integrated Economies (LFIs).

$\underline{\text { Table A.1. Country Sample }}$

$\begin{array}{llll}\text { Industrial Countries } & \text { MFIs } & \text { LFIs } & \text { LFIs (cont) } \\ \text { Australia } & \text { Argentina } & \text { Algeria } & \text { Niger } \\ \text { Austria } & \text { Brazil } & \text { Bangladesh } & \text { Nigeria } \\ \text { Belgium } & \text { Chile } & \text { Bolivia } & \text { Panama } \\ \text { Canada } & \text { China } & \text { Burkina Faso } & \text { Papua New Guinea } \\ \text { Denmark } & \text { Colombia } & \text { Burundi } & \text { Paraguay } \\ \text { Finland } & \text { Egypt } & \text { Cameroon } & \text { Senegal } \\ \text { France } & \text { Hong Kong } & \text { Costa Rica } & \text { Sierra Leone } \\ \text { Germany } & \text { India } & \text { Cote d'Ivoire } & \text { Sri Lanka } \\ \text { Greece } & \text { Indonesia } & \text { Dominican Republic } & \text { Tanzania } \\ \text { Ireland } & \text { Israel } & \text { Ecuador } & \text { Togo } \\ \text { Italy } & \text { Jordan } & \text { El Salvador } & \text { Trinidad and Tobago } \\ \text { Japan } & \text { Korea } & \text { Fiji } & \text { Tunisia } \\ \text { Netherlands } & \text { Malaysia } & \text { Gabon } & \text { Uruguay } \\ \text { New Zealand } & \text { Mexico } & \text { Ghana } & \text { Zambia } \\ \text { Norway } & \text { Morocco } & \text { Guatemala } & \text { Zimbabwe } \\ \text { Portugal } & \text { Pakistan } & \text { Guyana } & \\ \text { Spain } & \text { Peru } & \text { Haiti } & \\ \text { Sweden } & \text { Philippines } & \text { Honduras } & \\ \text { Switzerland } & \text { Singapore } & \text { Iran } & \\ \text { United Kingdom } & \text { South Africa } & \text { Jamaica } & \\ \text { United States } & \text { Thailand } & \text { Kenya } & \\ & \text { Turkey } & \text { Lesotho } & \\ & \text { Venezuela } & \text { Malawi } & \\ & & \text { Mauritius } & \\ & & \text { Nepal } & \\ & & \text { Nicaragua } & \\ & & & \\ & & & \end{array}$

${ }^{29}$ We excluded from the analysis small countries (those with population below 1 million), transition economies, some oil producers, and other countries with incomplete or clearly unreliable data. 
$\underline{\text { Table A.2. Variables }}$

$\underline{\text { Variable description }}$

Real GDP per capita, constant local currency units.

Private consumption per capita, constant local currency units. PWT

Investment per capita, constant local currency units

General government consumption per capita, constant local currency units.

Imports of goods and services per capita, constant local currency units.

Exports of goods and services per capita, constant local currency units.

Trade openness. Sum of exports and imports divided by GDP.

Capital inflows, percent of GDP. Sum of foreign direct investment, portfolio flows, and other investments.

Capital outflows, percent of GDP. Sum of foreign direct investment, portfolio flows, and other investments.

Financial openness. Gross capital flows

(sum of capital inflows and outflows).

Terms of trade $(1995=100)$.

Trade and capital account restrictions. Includes payment restrictions for current and capital account, export surrender requirements, and multiple exchange rates.

Consumer price index $(1995=100)$.

Money and quasi-money (M2), percent of GDP.

Exchange rate arrangement, de facto.

Population.

\section{$\underline{\text { Source }}$}

PWT

PWT

PWT

PWT

PWT

IFS,

Lane and Milesi-Ferreti

IFS,

Lane and Milesi-Ferreti
IMF

IMF

WDI, IFS

WDI

Reinhart and Rogoff

WDI 
$\underline{\text { Table A.2. (cont) }}$

Variable description

Share of the population that lives in rural areas.

Shares of manufactures and agricultural production in GDP. WDI

Secondary Education

Credit

Property Rights

Executive Constraints

Political Stability
Source

WDI

WDI

Beck, Demirguc-Kunt, and Levine (1999)

Heritage Foundation

Gurr and Marshall

Gurr and Marshall

\section{Appendix B [to be added}


Table 1

Growth and Volatility: Descriptive Statistics

(Medians for each group of countries)

\begin{tabular}{|c|c|c|c|c|c|}
\hline & \multirow{2}{*}{$\begin{array}{c}\text { Full Sample } \\
1961-2000\end{array}$} & \multicolumn{4}{|c|}{ Decade } \\
\hline & & $1960 \mathrm{~s}$ & $1970 \mathrm{~s}$ & $1980 \mathrm{~s}$ & $1990 \mathrm{~s}$ \\
\hline \multicolumn{6}{|l|}{$\overline{\text { Output }}$} \\
\hline \multicolumn{6}{|l|}{ Growth } \\
\hline \multirow[t]{2}{*}{ Industrial Countries } & 2.80 & 3.75 & 2.75 & 2.09 & 1.88 \\
\hline & {$[0.24]$} & {$[0.49]$} & {$[0.38]$} & {$[0.17]$} & {$[0.26]$} \\
\hline \multirow[t]{2}{*}{ Developing Countries } & 1.57 & 2.46 & 2.06 & 0.32 & 1.39 \\
\hline & {$[0.21]$} & {$[0.22]$} & {$[0.40]$} & {$[0.36] \psi$} & {$[0.38]$} \\
\hline \multirow[t]{2}{*}{ MFIs } & 2.61 & 3.06 & 2.80 & 1.76 & 2.45 \\
\hline & {$[0.41]$} & {$[0.53]$} & {$[0.99]$} & {$[1.18] \psi$} & {$[0.70]$} \\
\hline \multirow[t]{2}{*}{ LFIs } & 1.23 & 2.25 & 1.77 & -0.27 & 0.83 \\
\hline & {$[0.25]$} & {$[0.36]$} & {$[0.56]$} & {$[0.36] \psi$} & {$[0.67] \psi$} \\
\hline \multicolumn{6}{|l|}{ Volatility } \\
\hline \multirow[t]{2}{*}{ Industrial Countries } & 2.59 & 2.18 & 2.78 & 2.12 & 1.79 \\
\hline & {$[0.36]$} & {$[0.27]$} & {$[0.26]$} & {$[0.22]$} & {$[0.28]$} \\
\hline \multirow[t]{2}{*}{ Developing Countries } & 4.90 & 4.62 & 4.83 & 3.89 & 3.39 \\
\hline & {$[0.30]$} & {$[0.46]$} & {$[0.58]$} & {$[0.24]$} & {$[0.30]$} \\
\hline \multirow[t]{2}{*}{ MFIs } & 4.07 & 3.29 & 3.35 & 3.56 & 3.27 \\
\hline & {$[0.42]$} & {$[0.57]$} & {$[0.43]$} & {$[0.64]$} & {$[0.51]$} \\
\hline \multirow[t]{2}{*}{ LFIs } & 5.38 & 4.82 & 6.40 & 4.05 & 3.39 \\
\hline & {$[0.61]$} & {$[0.56]$} & {$[0.52]$} & {$[0.31]$} & {$[0.37]$} \\
\hline \multicolumn{6}{|l|}{ Consumption } \\
\hline \multicolumn{6}{|l|}{ Growth } \\
\hline \multirow[t]{2}{*}{ Industrial Countries } & 2.71 & 3.33 & 3.02 & 2.44 & 1.82 \\
\hline & {$[0.26]$} & {$[0.62]$} & {$[0.38]$} & {$[0.40]$} & {$[0.36]$} \\
\hline \multirow[t]{2}{*}{ Developing Countries } & 1.26 & 1.93 & 2.00 & 0.25 & 1.48 \\
\hline & {$[0.20]$} & {$[0.37]$} & {$[0.33]$} & {$[0.42] \psi$} & {$[0.35]$} \\
\hline \multirow[t]{2}{*}{ MFIs } & 1.89 & 2.88 & 2.89 & 0.92 & 2.25 \\
\hline & {$[0.52]$} & {$[0.46]$} & {$[0.70]$} & {$[1.08] \psi$} & {$[0.53]$} \\
\hline \multirow[t]{2}{*}{ LFIs } & 0.82 & 1.15 & 1.63 & -0.76 & 0.83 \\
\hline & {$[0.19]$} & {$[0.33]$} & {$[0.28]$} & {$[0.37]^{* *}$} & {$[0.54] \psi$} \\
\hline \multicolumn{6}{|l|}{ Volatility } \\
\hline \multirow[t]{2}{*}{ Industrial Countries } & 3.32 & 2.32 & 2.30 & 2.47 & 1.58 \\
\hline & {$[0.62]$} & {$[0.39]$} & {$[0.25]$} & {$[1.09]^{* *}$} & {$[0.71]^{* *}$} \\
\hline \multirow[t]{2}{*}{ Developing Countries } & 6.91 & 5.70 & 6.29 & 6.23 & 5.15 \\
\hline & {$[0.43]$} & {$[0.34]$} & {$[0.51]$} & {$[0.47]$} & {$[0.48]$} \\
\hline \multirow[t]{2}{*}{ MFIs } & 5.63 & 5.13 & 5.54 & 4.70 & 4.73 \\
\hline & {$[0.64]$} & {$[0.56]$} & {$[0.91]$} & {$[0.67]$} & {$[0.73]$} \\
\hline \multirow[t]{2}{*}{ LFIs } & 7.99 & 6.35 & 7.21 & 7.19 & 5.58 \\
\hline & {$[0.66]$} & {$[0.45]$} & {$[0.92]$} & {$[0.55]$} & {$[0.64]$} \\
\hline
\end{tabular}

Notes: Standard errors are in brackets. The symbols **, and * indicate statistical significance at the 10 percent and 5 percent levels, respectively. The symbol $\psi$ indicates the value is not significant. All other values (unmarked) are significant at 1 percent. 
Table 1 (continued)

\section{Growth and Volatility: Descriptive Statistics (Medians for each group of countries)}

\begin{tabular}{|c|c|c|c|c|c|}
\hline & \multirow{2}{*}{$\begin{array}{c}\text { Full Sample } \\
1961-2000\end{array}$} & \multicolumn{4}{|c|}{ Decade } \\
\hline & & $1960 \mathrm{~s}$ & $1970 \mathrm{~s}$ & $1980 \mathrm{~s}$ & $1990 \mathrm{~s}$ \\
\hline \multicolumn{6}{|l|}{ Investment } \\
\hline \multicolumn{6}{|l|}{ Growth } \\
\hline \multirow[t]{2}{*}{ Industrial Countries } & 2.78 & 5.00 & 1.49 & 2.67 & 2.10 \\
\hline & {$[0.36]$} & {$[1.14]$} & {$[0.88] \psi$} & {$[0.38]$} & {$[0.65]$} \\
\hline \multirow[t]{2}{*}{ Developing Countries } & 2.03 & 4.61 & 4.06 & -1.71 & 2.02 \\
\hline & {$[0.36]$} & {$[0.52]$} & [1.13] & {$[0.82]^{* *}$} & {$[0.94]^{* *}$} \\
\hline \multirow[t]{2}{*}{ MFIs } & 2.68 & 4.63 & 4.55 & 1.71 & 2.64 \\
\hline & {$[0.78]$} & {$[0.99]$} & {$[1.50]$} & {$[1.35]$} & {$[0.93]$} \\
\hline \multirow[t]{2}{*}{ LFIs } & 1.31 & 4.30 & 4.06 & -3.00 & 2.02 \\
\hline & {$[0.47]$} & {$[0.76]$} & {$[1.82]^{* *}$} & {$[0.85]$} & {$[1.26] \psi$} \\
\hline \multicolumn{6}{|l|}{ Volatility } \\
\hline \multirow[t]{2}{*}{ Industrial Countries } & 9.16 & 7.40 & 10.53 & 8.36 & 7.11 \\
\hline & {$[0.90]$} & {$[0.86]$} & [1.29] & {$[1.55]$} & {$[0.72]$} \\
\hline \multirow[t]{2}{*}{ Developing Countries } & 18.37 & 18.24 & 18.24 & 16.27 & 15.14 \\
\hline & {$[1.27]$} & {$[1.66]$} & {$[1.38]$} & {$[1.37]$} & {$[1.10]$} \\
\hline \multirow[t]{2}{*}{ MFIs } & 15.76 & 14.48 & 11.32 & 13.27 & 14.18 \\
\hline & [1.74] & {$[3.00]$} & [2.73] & {$[3.26]$} & [2.37] \\
\hline \multirow[t]{2}{*}{ LFIs } & 21.80 & 19.12 & 20.28 & 17.40 & 15.14 \\
\hline & [1.42] & {$[1.77]$} & {$[1.62]$} & {$[1.10]$} & {$[1.24]$} \\
\hline \multicolumn{6}{|l|}{ Exports } \\
\hline \multicolumn{6}{|l|}{ Growth } \\
\hline \multirow[t]{2}{*}{ Industrial Countries } & 5.27 & 7.07 & 4.96 & 4.33 & 5.60 \\
\hline & {$[0.38]$} & {$[0.92]$} & {$[0.53]$} & {$[0.28]$} & {$[0.71]$} \\
\hline \multirow[t]{2}{*}{ Developing Countries } & 2.55 & 2.77 & 3.23 & 2.23 & 3.47 \\
\hline & {$[0.49]$} & {$[0.54]$} & {$[0.94]$} & {$[0.66]$} & {$[0.73]$} \\
\hline \multirow[t]{2}{*}{ MFIs } & 4.95 & 2.60 & 5.21 & 4.35 & 6.04 \\
\hline & [1.03] & {$[0.77]$} & [1.01] & [1.32] & [1.39] \\
\hline \multirow[t]{2}{*}{ LFIs } & 1.82 & 3.25 & 2.20 & 1.11 & 1.94 \\
\hline & {$[0.40]$} & {$[1.16]$} & {$[1.05]^{* *}$} & {$[0.99] \psi$} & {$[1.00]^{*}$} \\
\hline \multicolumn{6}{|l|}{ Volatility } \\
\hline \multirow[t]{2}{*}{ Industrial Countries } & 4.67 & 3.95 & 5.26 & 3.51 & 3.89 \\
\hline & {$[0.42]$} & {$[0.84]$} & {$[0.37]$} & {$[0.54]$} & {$[0.45]$} \\
\hline \multirow[t]{2}{*}{ Developing Countries } & 11.85 & 9.88 & 12.23 & 10.08 & 7.73 \\
\hline & {$[0.65]$} & {$[0.93]$} & [1.29] & {$[0.70]$} & {$[0.57]$} \\
\hline \multirow[t]{2}{*}{ MFIs } & 9.20 & 8.51 & 10.36 & 8.28 & 6.76 \\
\hline & {$[1.09]$} & {$[1.69]$} & {$[1.52]$} & {$[0.74]$} & {$[0.75]$} \\
\hline \multirow[t]{2}{*}{ LFIs } & 13.71 & 11.56 & 14.79 & 10.84 & 9.02 \\
\hline & {$[0.88]$} & {$[1.21]$} & [1.66] & {$[1.70]$} & [1.23] \\
\hline
\end{tabular}

Notes: Standard errors are in brackets. The symbols **, and * indicate statistical significance at the 10 percent and 5 percent levels, respectively. The symbol $\psi$ indicates the value is not significant. All other values (unmarked) are significant at 1 percent. 
Table 1 (continued)

Growth and Volatility: Descriptive Statistics

(Medians for each group of countries)

\begin{tabular}{|c|c|c|c|c|c|}
\hline & \multirow{2}{*}{$\begin{array}{c}\text { Full Sample } \\
1961-2000\end{array}$} & \multicolumn{4}{|c|}{ Decade } \\
\hline & & $1960 \mathrm{~s}$ & $1970 \mathrm{~s}$ & $1980 \mathrm{~s}$ & $1990 \mathrm{~s}$ \\
\hline \multicolumn{6}{|l|}{ Imports } \\
\hline \multicolumn{6}{|l|}{ Growth } \\
\hline \multirow{2}{*}{ Industrial Countries } & 5.16 & 7.59 & 4.05 & 3.92 & 5.07 \\
\hline & {$[0.40]$} & {$[0.81]$} & {$[0.61]$} & {$[0.42]$} & {$[0.40]$} \\
\hline \multirow[t]{2}{*}{ Developing Countries } & 2.46 & 3.14 & 4.28 & -0.58 & 3.41 \\
\hline & {$[0.46]$} & {$[0.56]$} & {$[0.61]$} & {$[0.97] \psi$} & {$[0.85]$} \\
\hline \multirow[t]{2}{*}{ MFIs } & 3.61 & 3.07 & 5.56 & 1.43 & 6.17 \\
\hline & {$[0.85]$} & {$[0.93]$} & {$[1.08]$} & {$[2.35] \psi$} & {$[1.07]$} \\
\hline \multirow[t]{2}{*}{ LFIs } & 1.82 & 3.14 & 3.74 & -1.75 & 1.56 \\
\hline & {$[0.54]$} & {$[0.78]$} & {$[1.04]$} & {$[1.09] \psi$} & {$[1.02]$} \\
\hline \multicolumn{6}{|l|}{ Volatility } \\
\hline \multirow[t]{2}{*}{ Industrial Countries } & 6.07 & 5.76 & 8.02 & 5.09 & 4.93 \\
\hline & {$[0.56]$} & {$[1.13]$} & {$[0.77]$} & {$[0.65]$} & {$[0.35]$} \\
\hline \multirow[t]{2}{*}{ Developing Countries } & 14.12 & 11.59 & 13.18 & 14.44 & 11.86 \\
\hline & [0.82] & {$[0.41]$} & {$[0.72]$} & {$[0.94]$} & {$[0.91]$} \\
\hline \multirow[t]{2}{*}{ MFIs } & 13.84 & 12.04 & 12.72 & 12.75 & 11.86 \\
\hline & {$[1.32]$} & {$[1.86]$} & {$[1.02]$} & {$[2.207]$} & {$[1.50]$} \\
\hline \multirow[t]{2}{*}{ LFIs } & 15.21 & 11.23 & 13.18 & 15.44 & 11.48 \\
\hline & [1.26] & {$[0.58]$} & [1.116] & {$[0.94]$} & {$[1.29]$} \\
\hline
\end{tabular}

Notes: Standard errors are in brackets. The symbols $* *$, and * indicate statistical significance at the 10 percent and 5 percent levels, respectively. The symbol $\psi$ indicates the value is not significant. All other values (unmarked) are significant at 1 percent. 


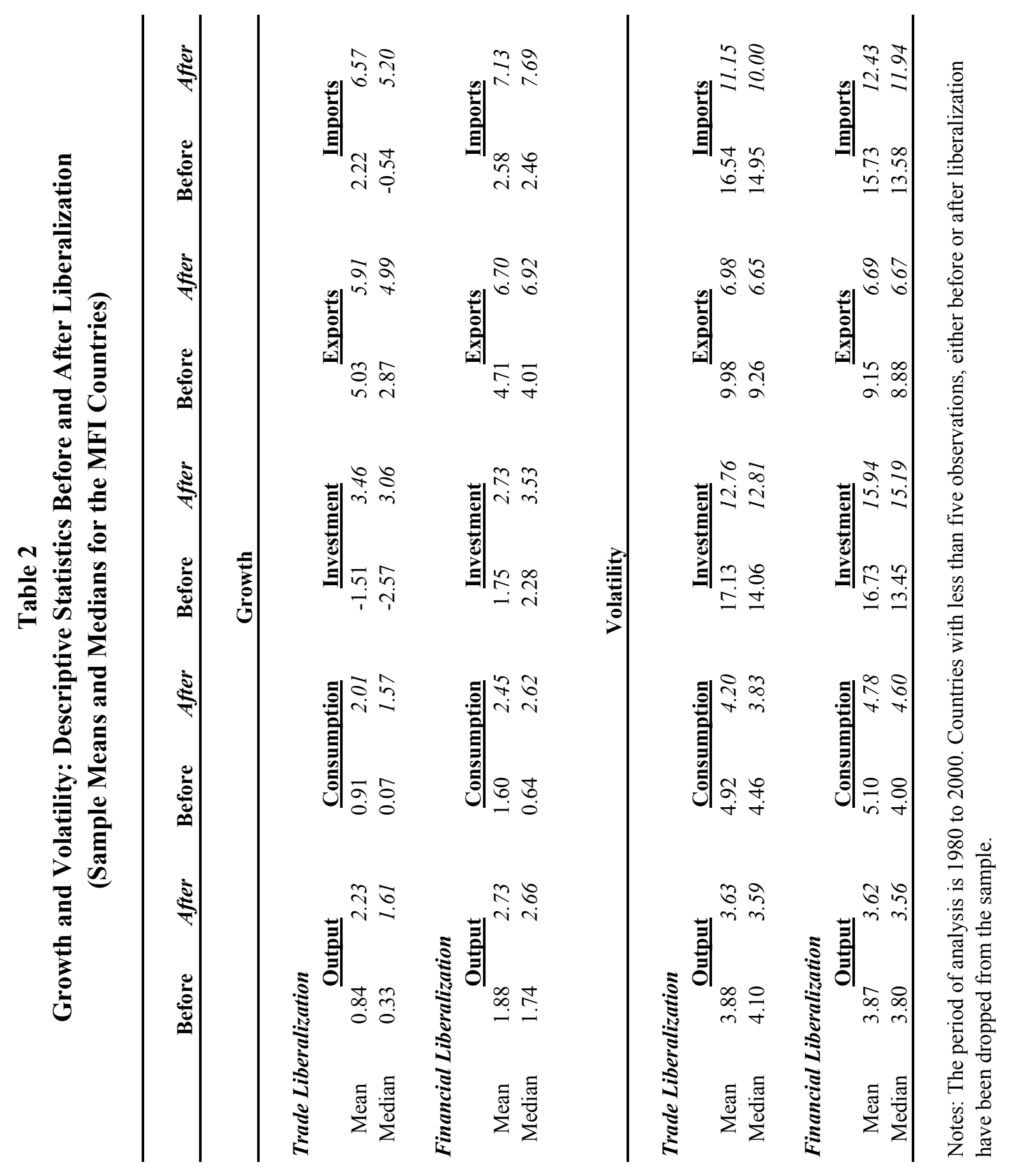




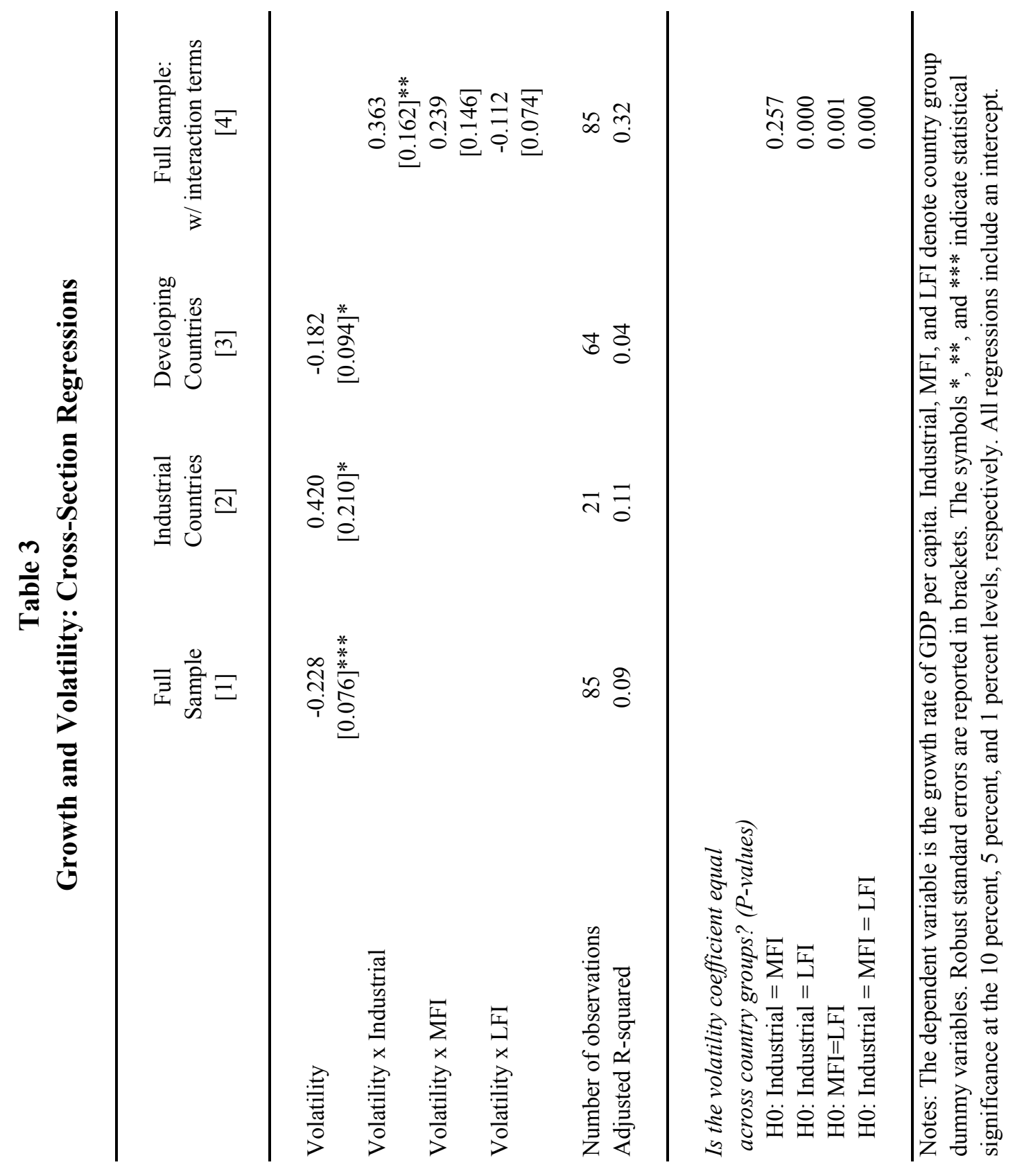




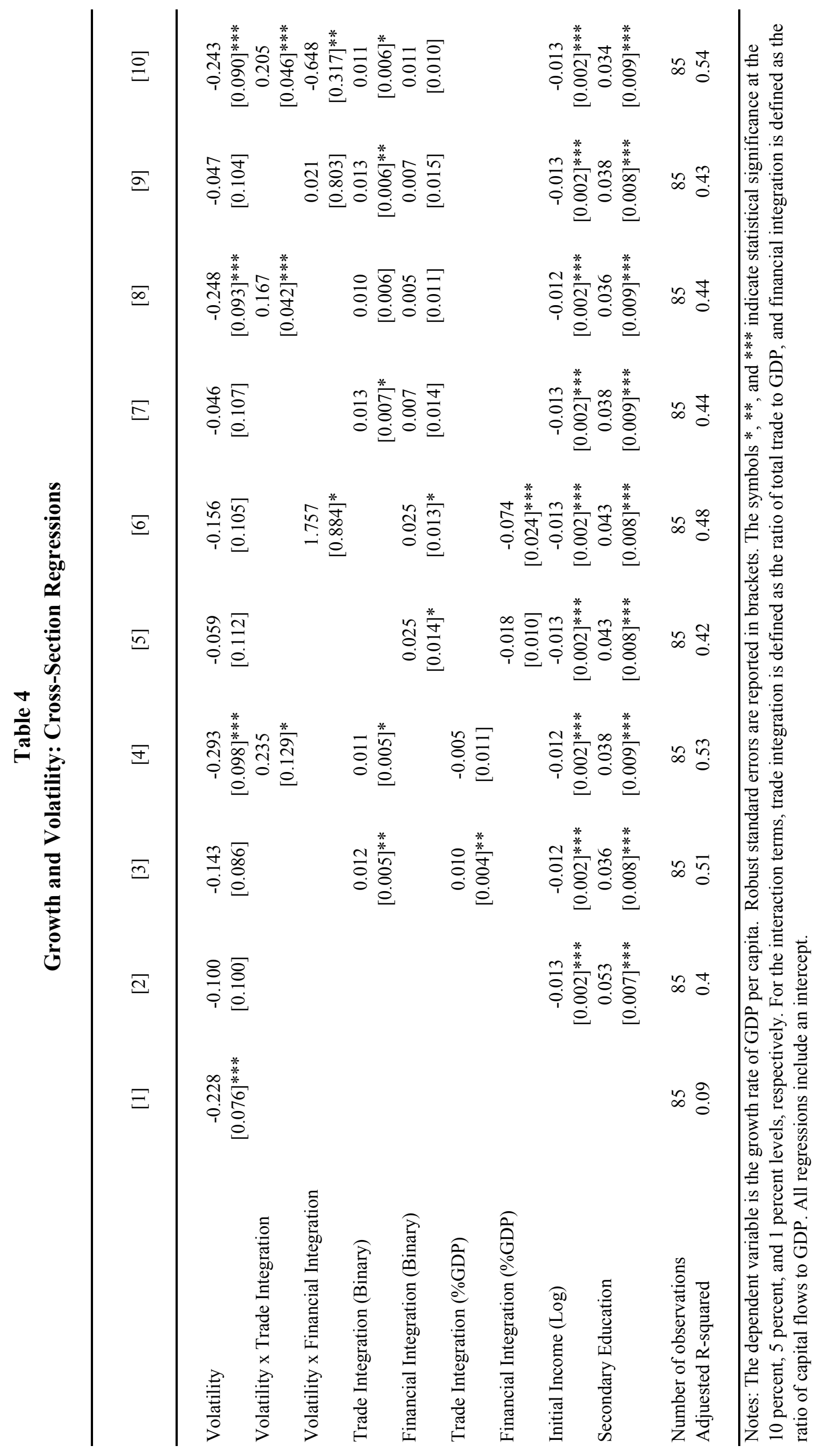




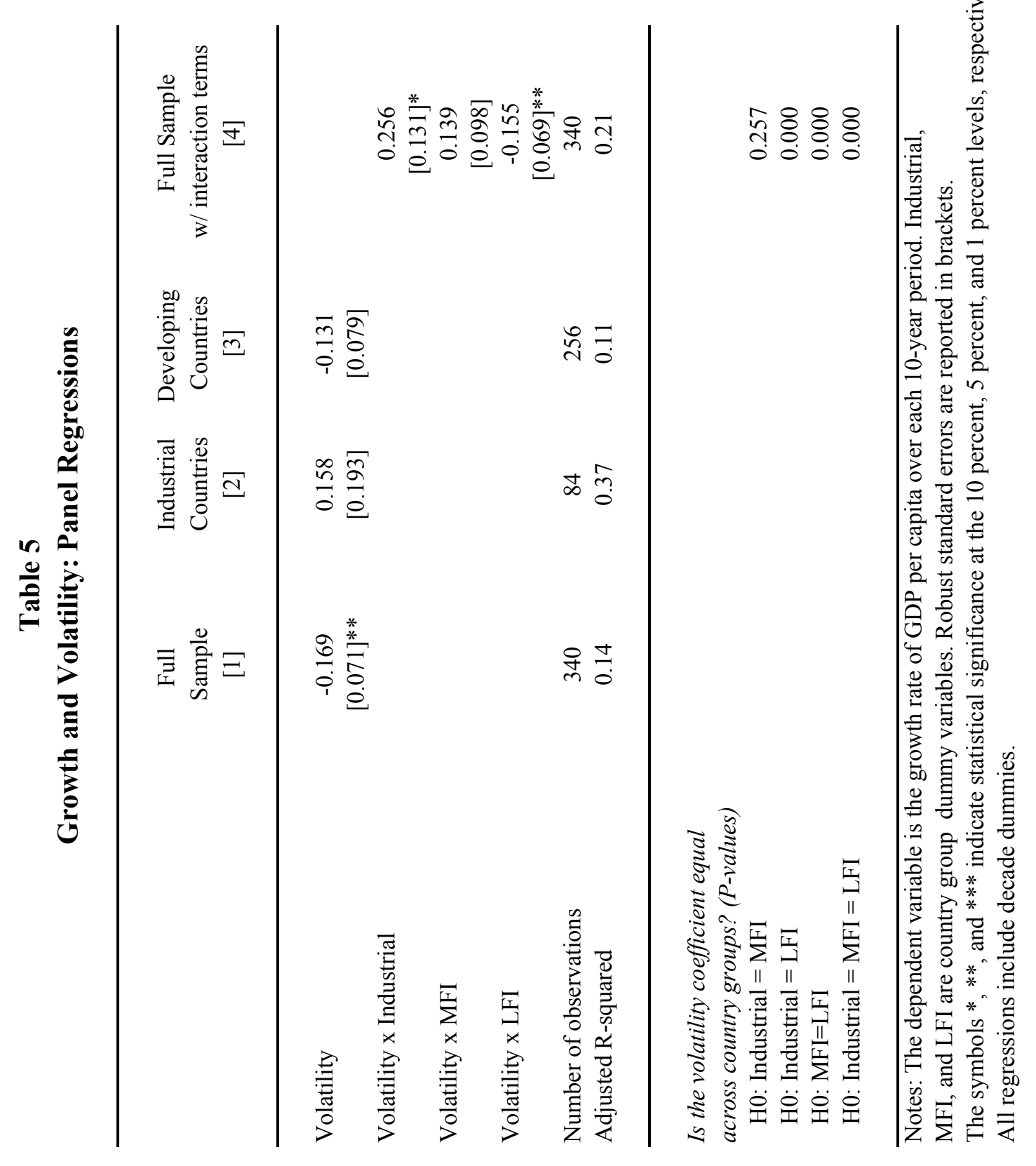




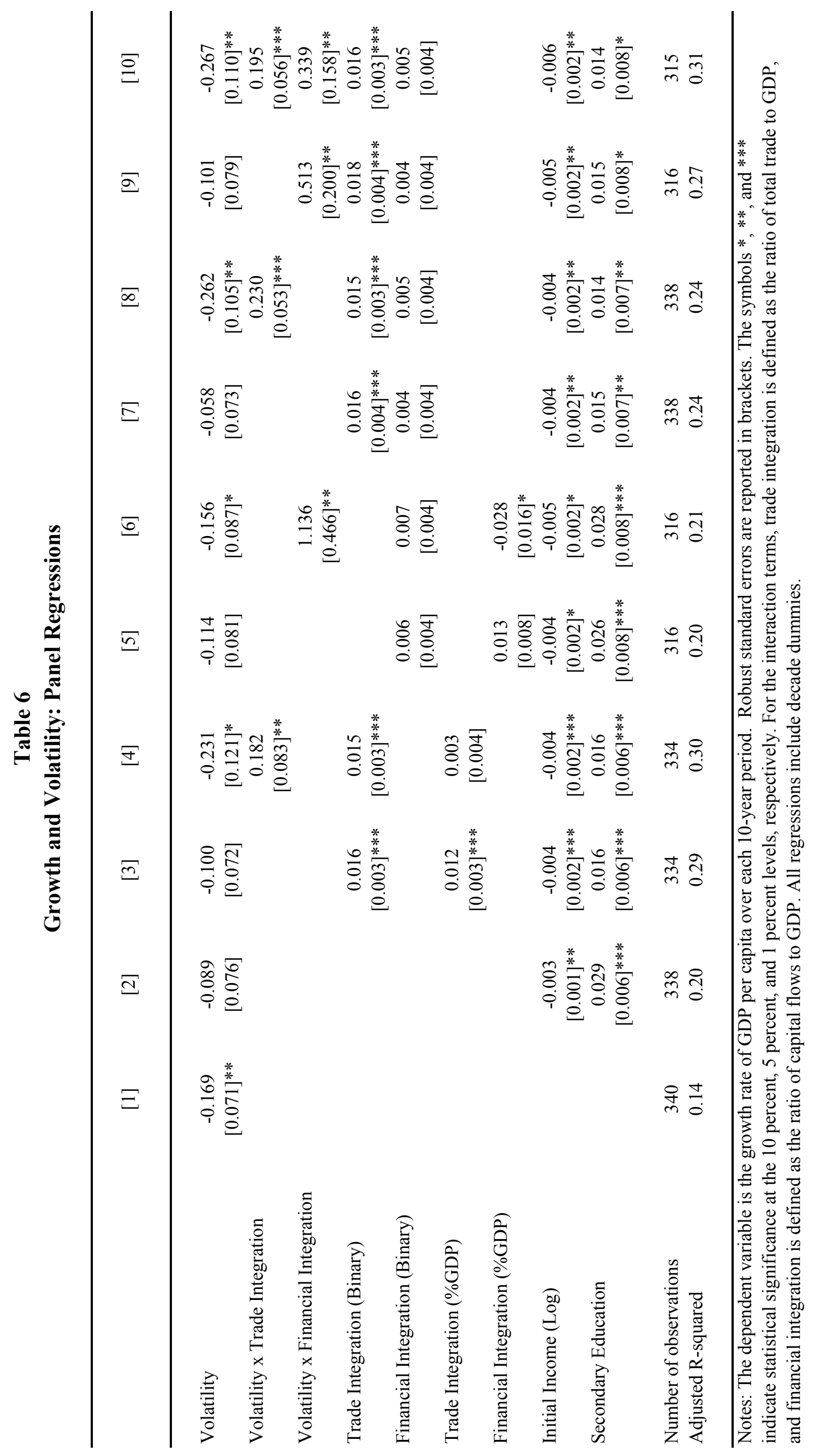




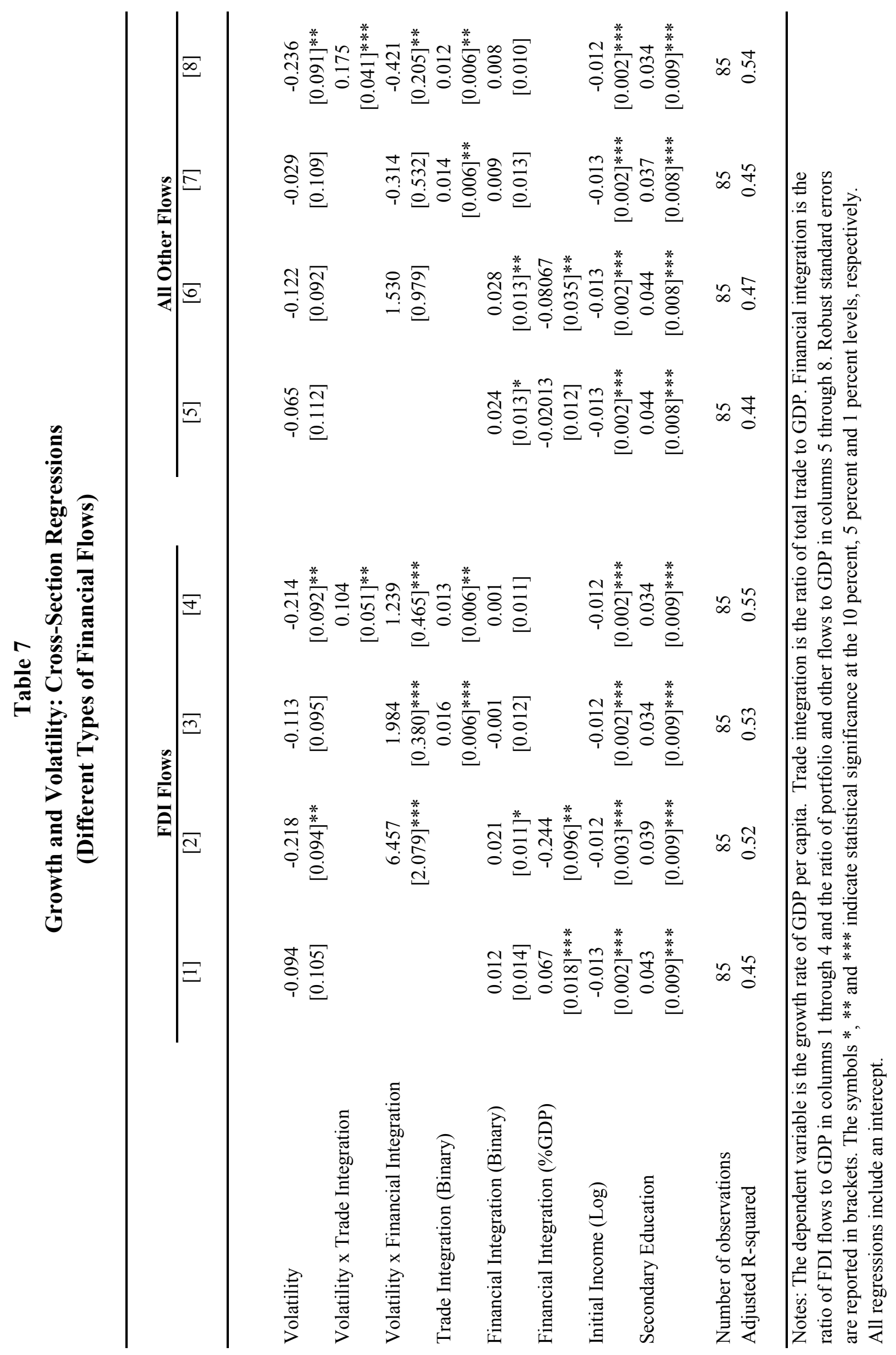




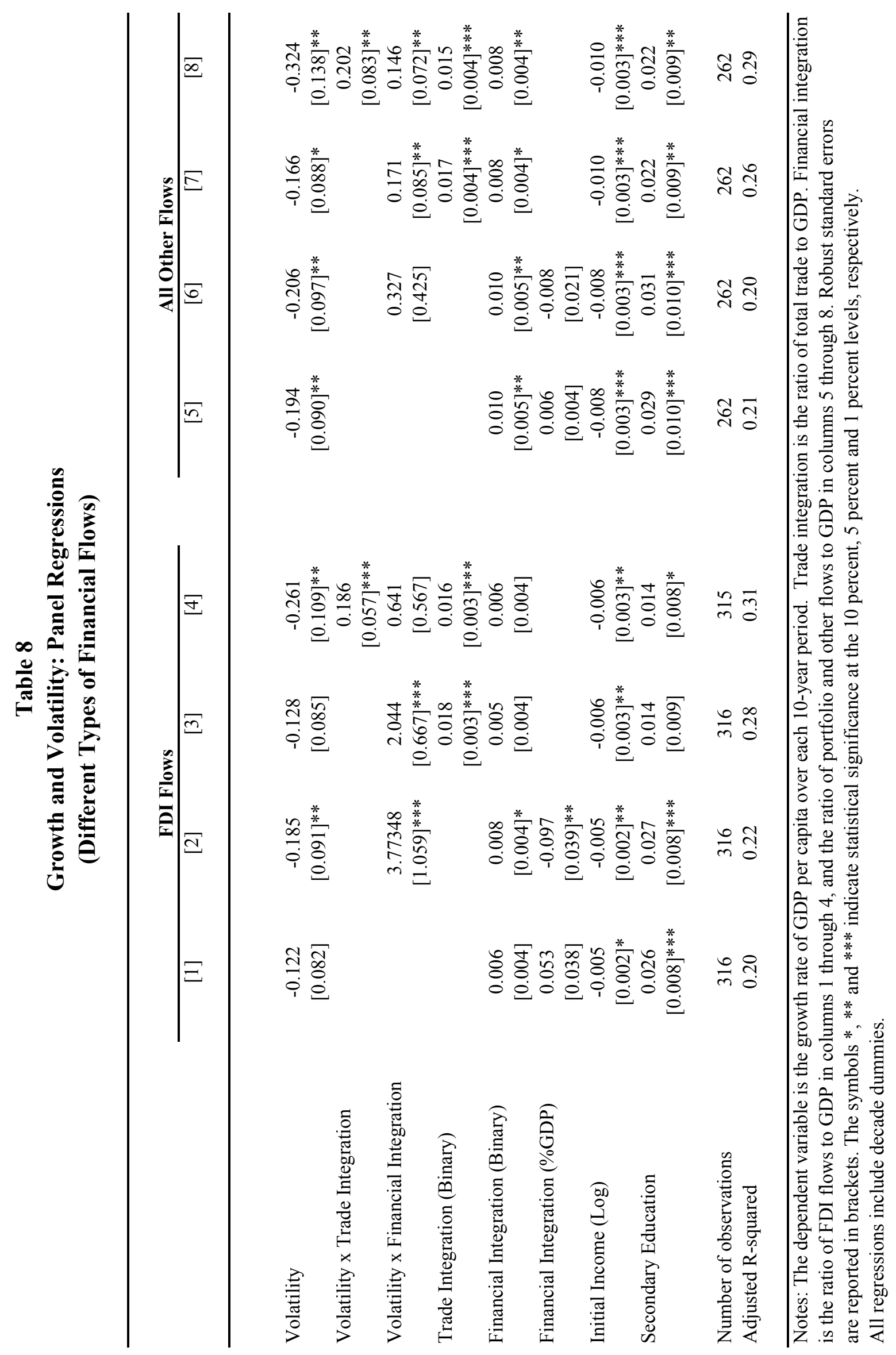




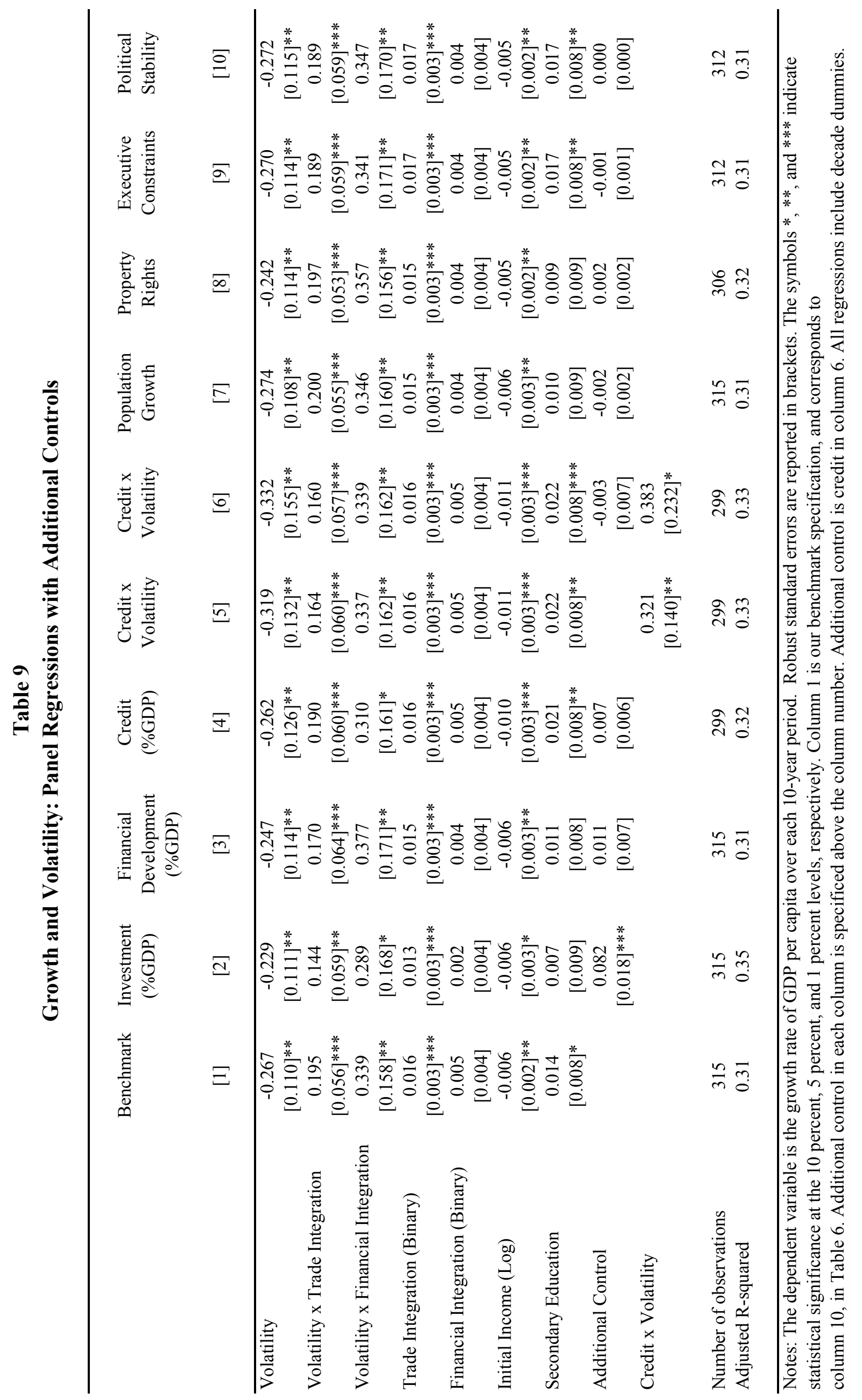




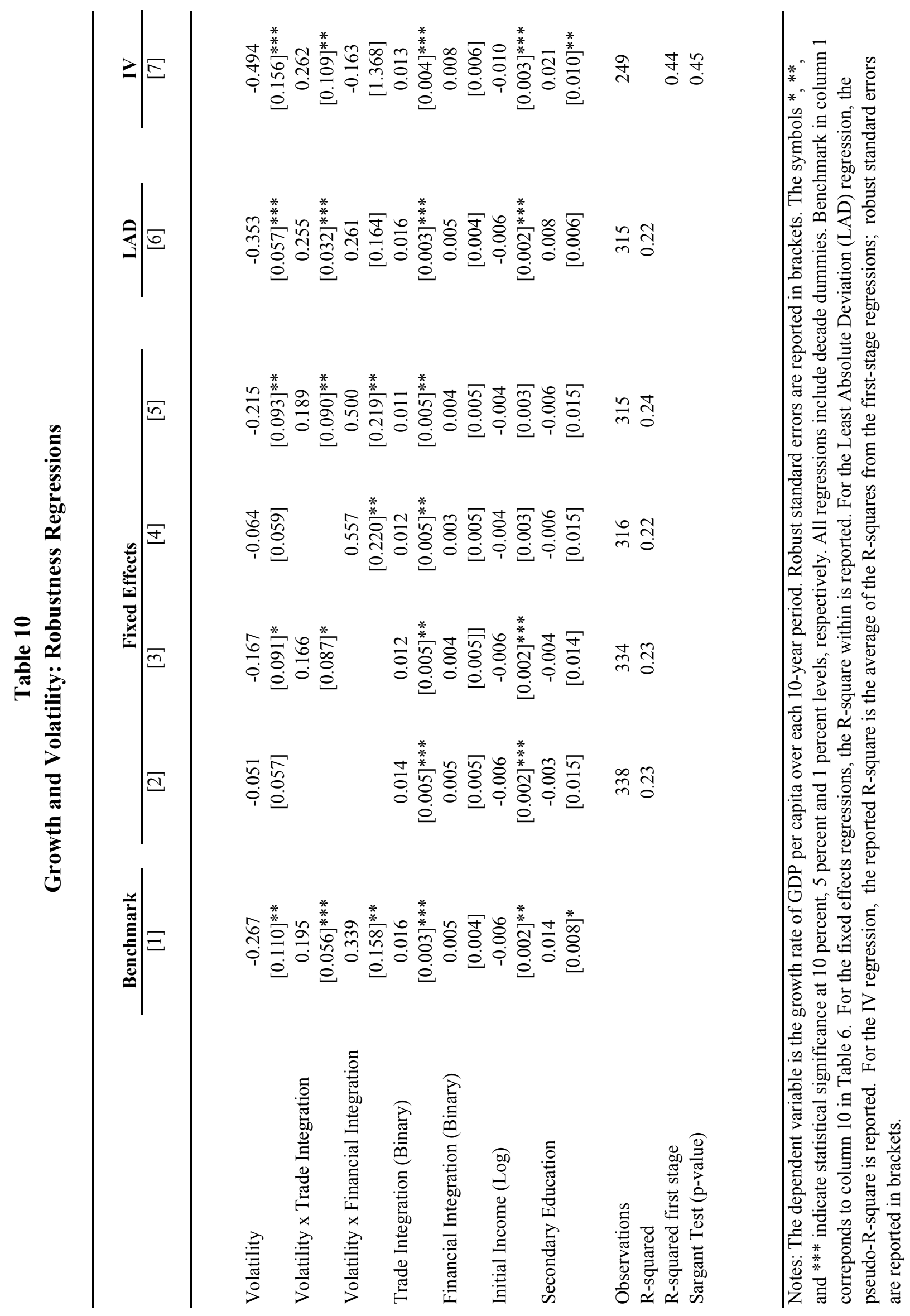


Figure 1

The Relationship between Volatility and Growth

Results of Empirical Studies

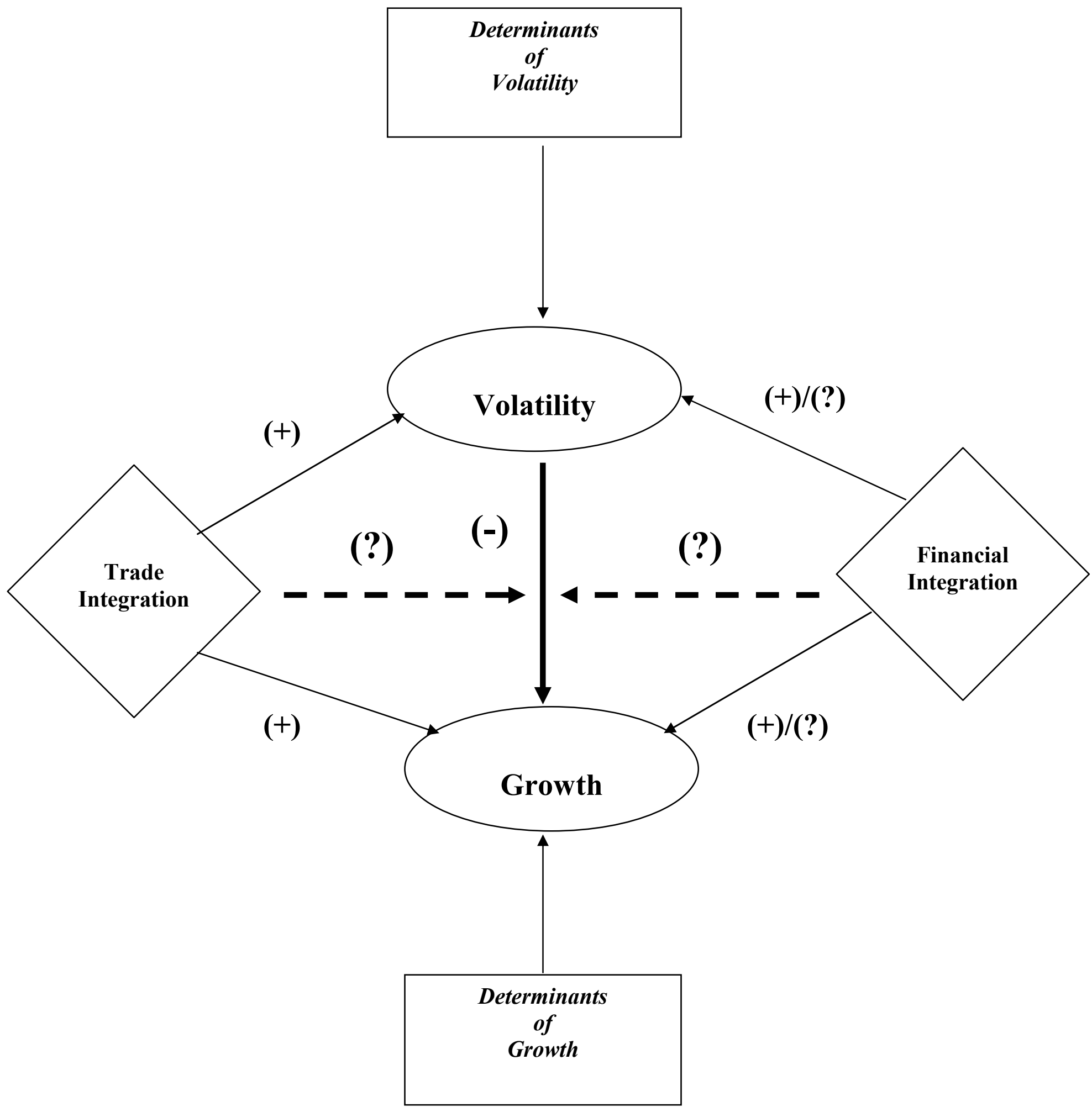


Figure 2

Rising Financial and Trade Linkages
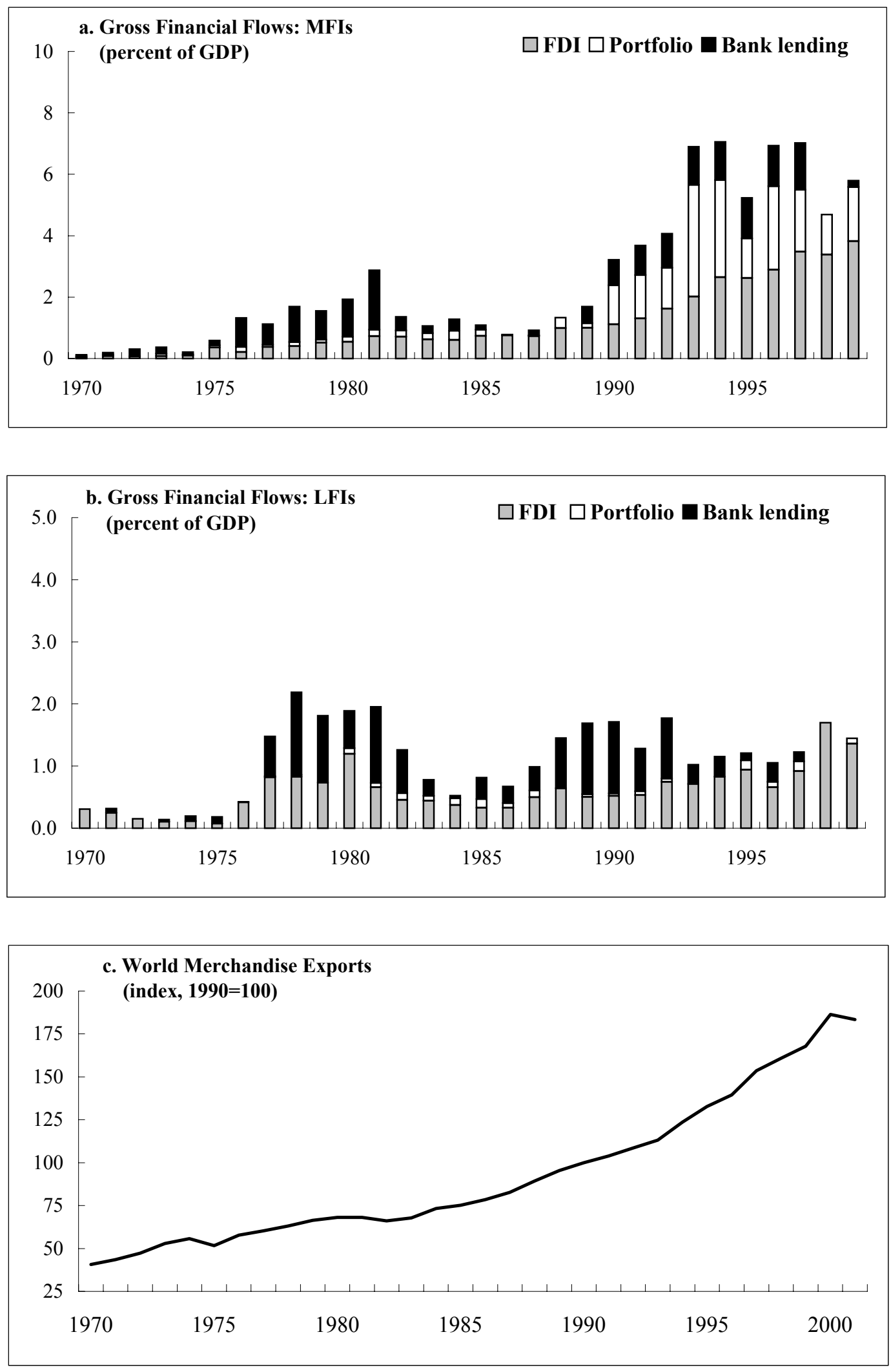

Notes: The top two panels do not have the same scale. 
Figure 3

Financial and Trade Liberalization
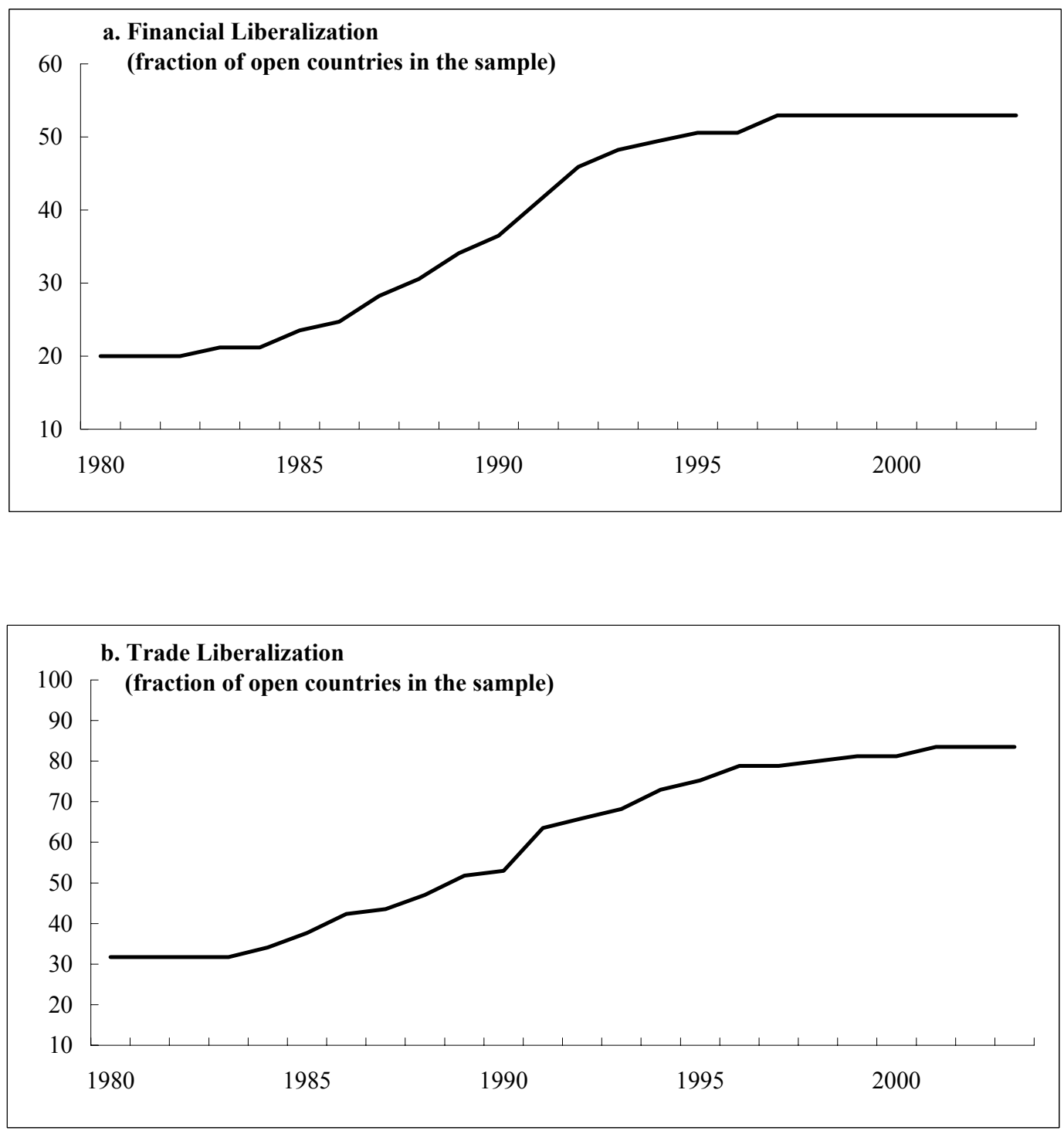


\section{Figure 4 \\ Growth and Volatility \\ (Simple Correlation, 1960-2000)}

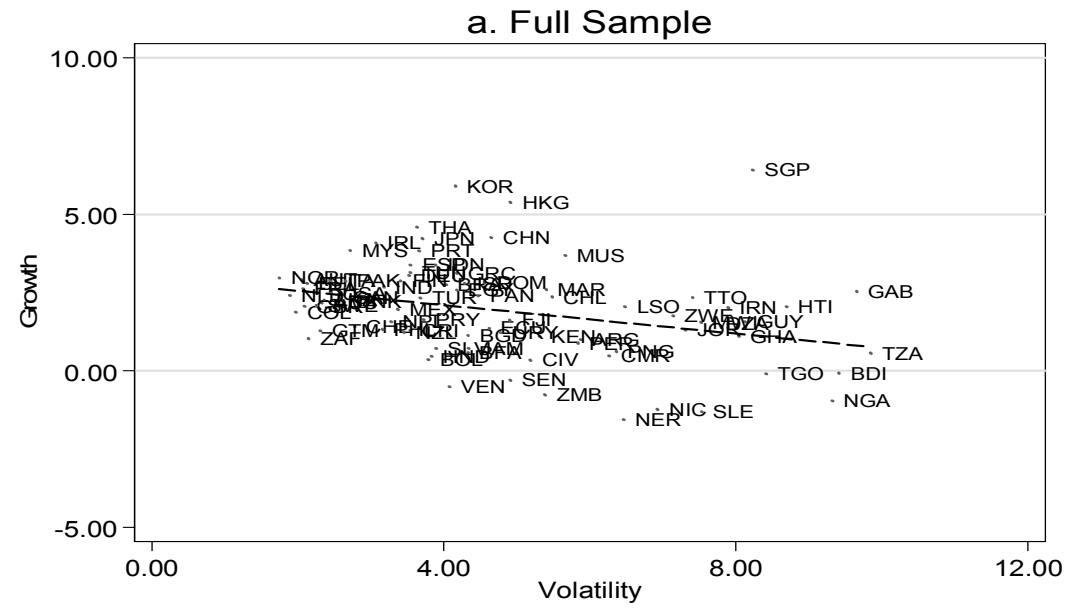

b. Industrial Countries

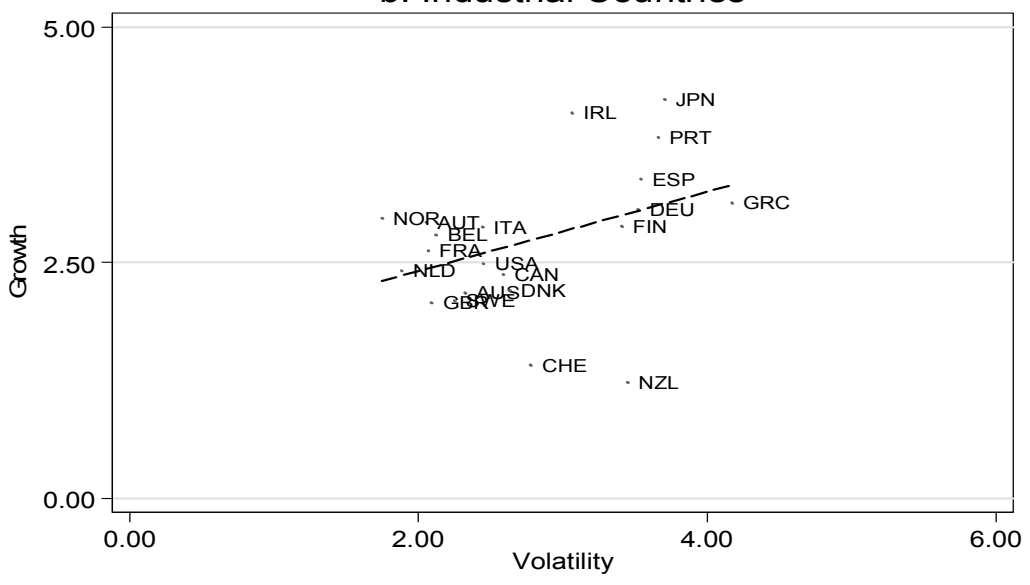

c. Developing Countries

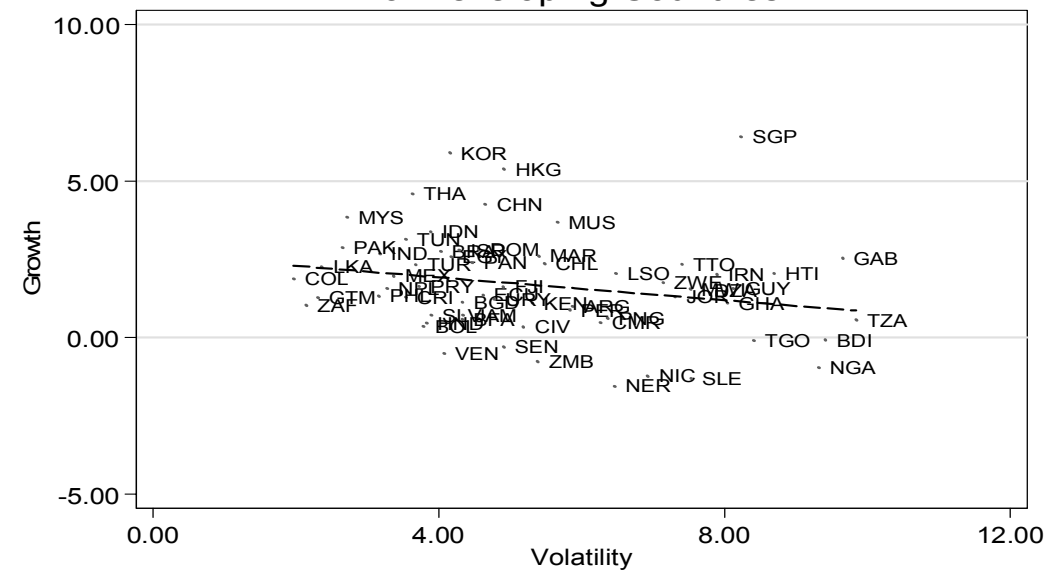


Figure 5

Growth and Volatility

(Simple Correlation, 1960-2000)

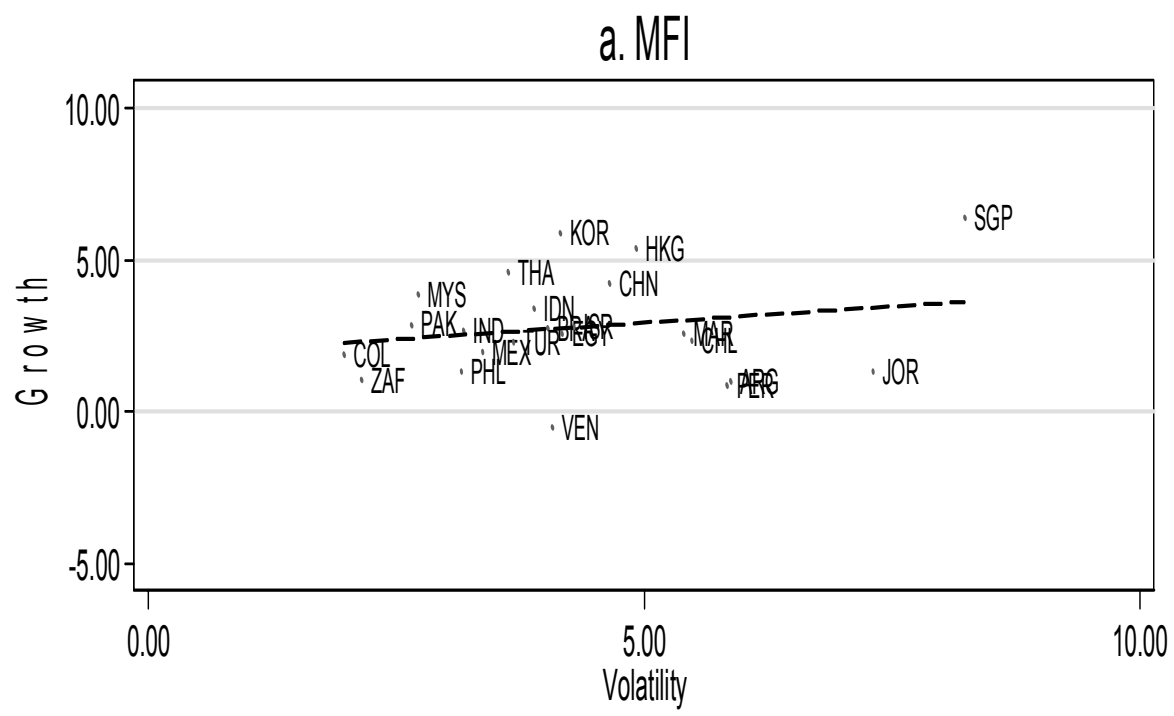

b. LFI

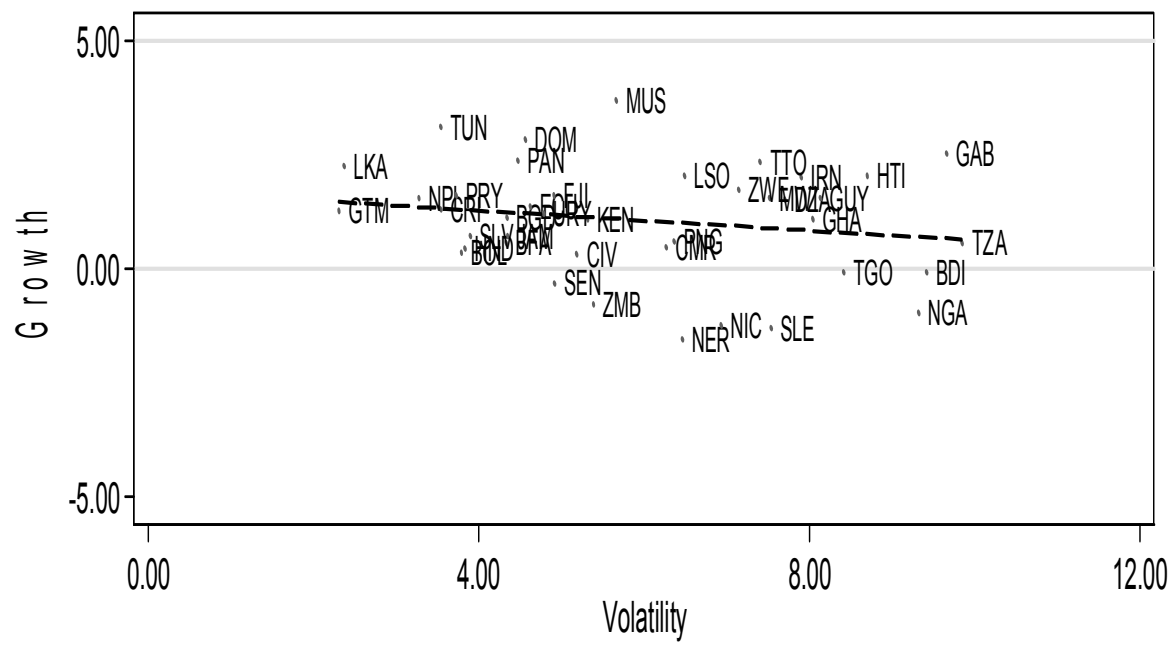




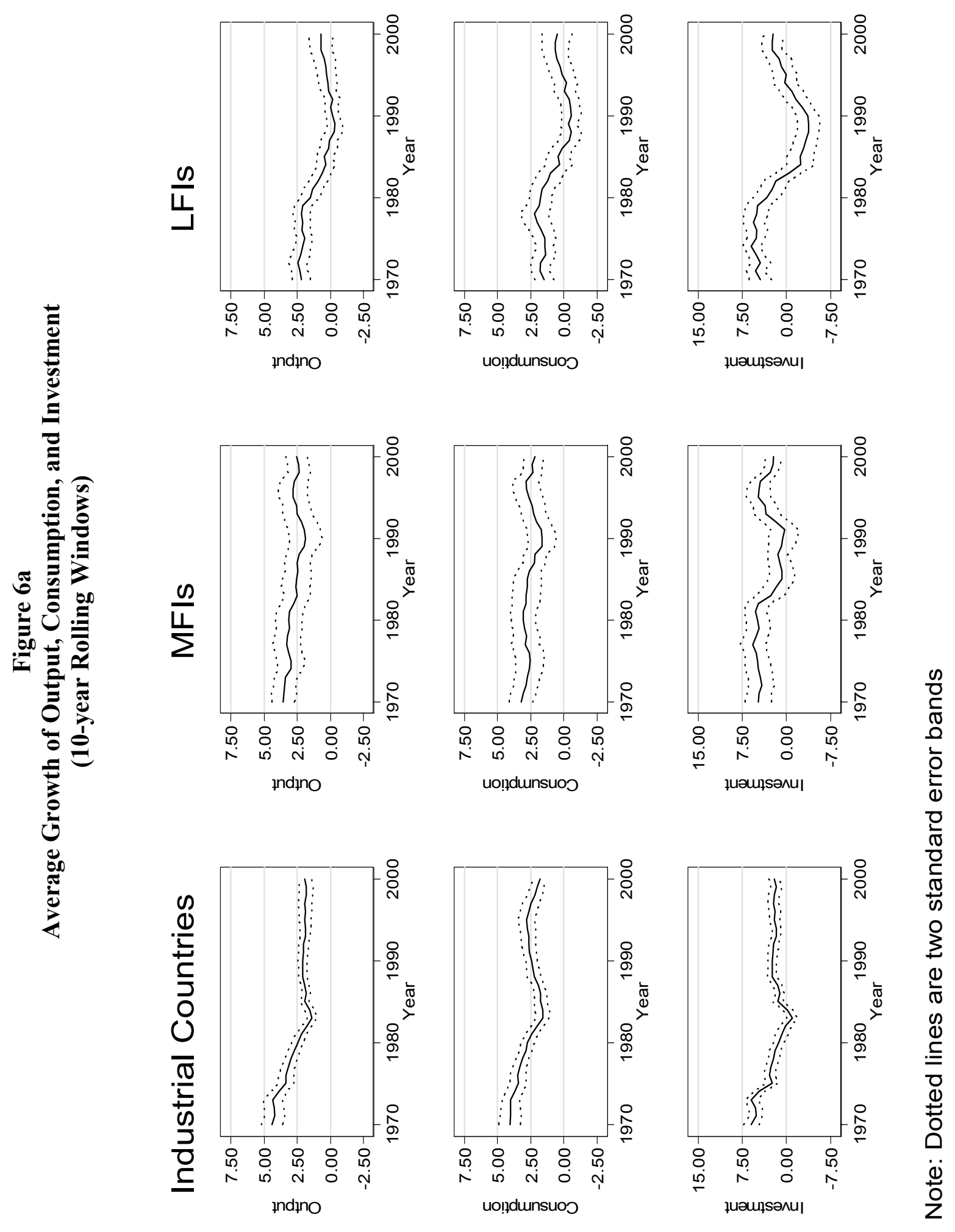



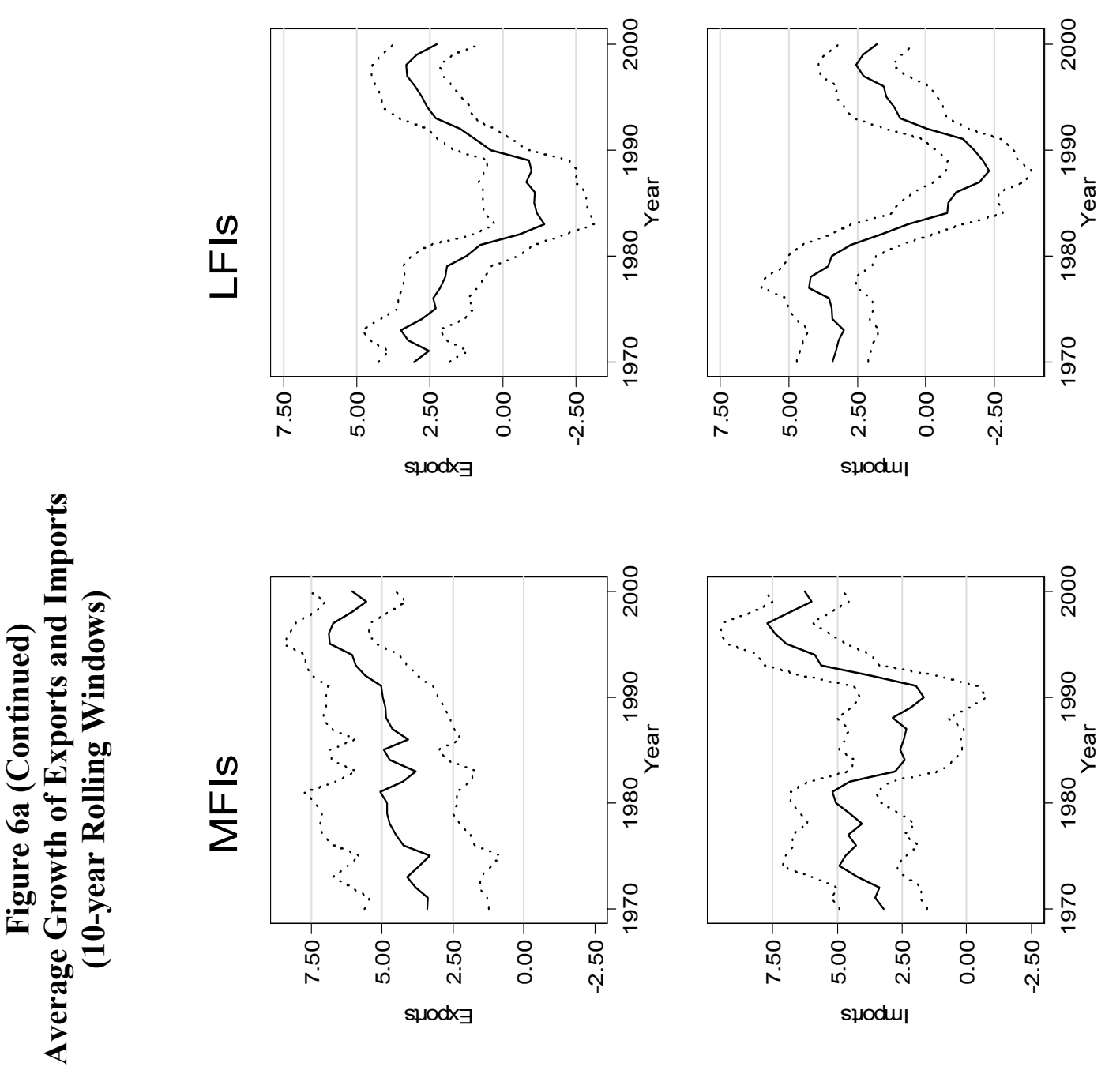

$\frac{0}{0}$
$\frac{1}{10}$
$\frac{0}{2}$
$\frac{1}{0}$
$\frac{1}{1}$
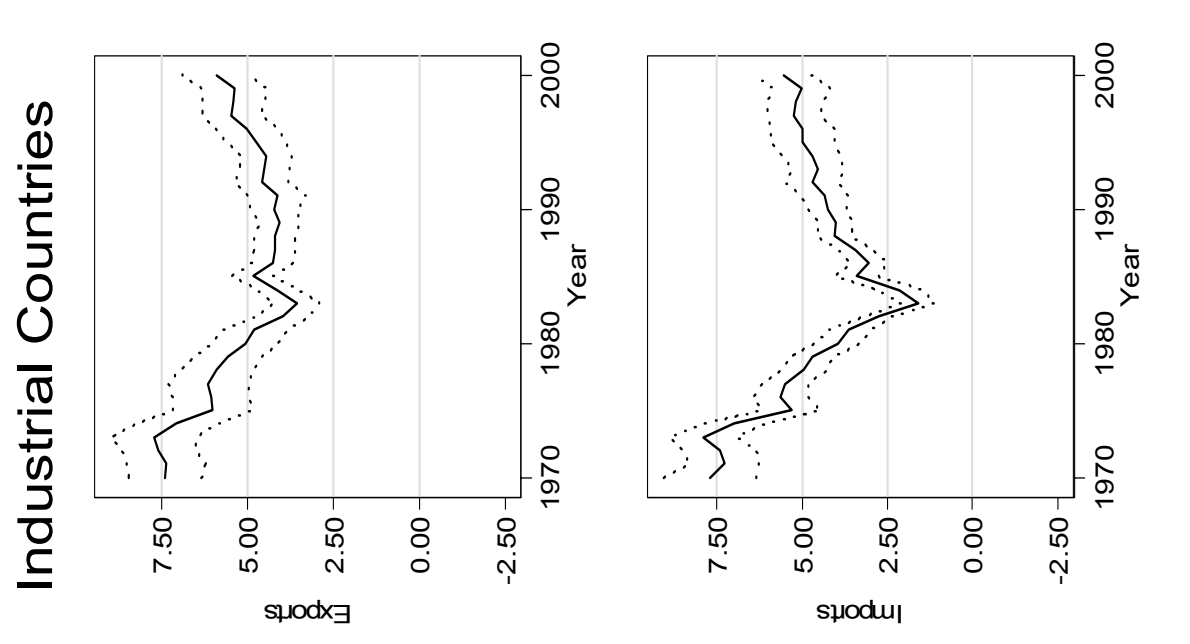

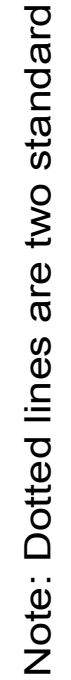




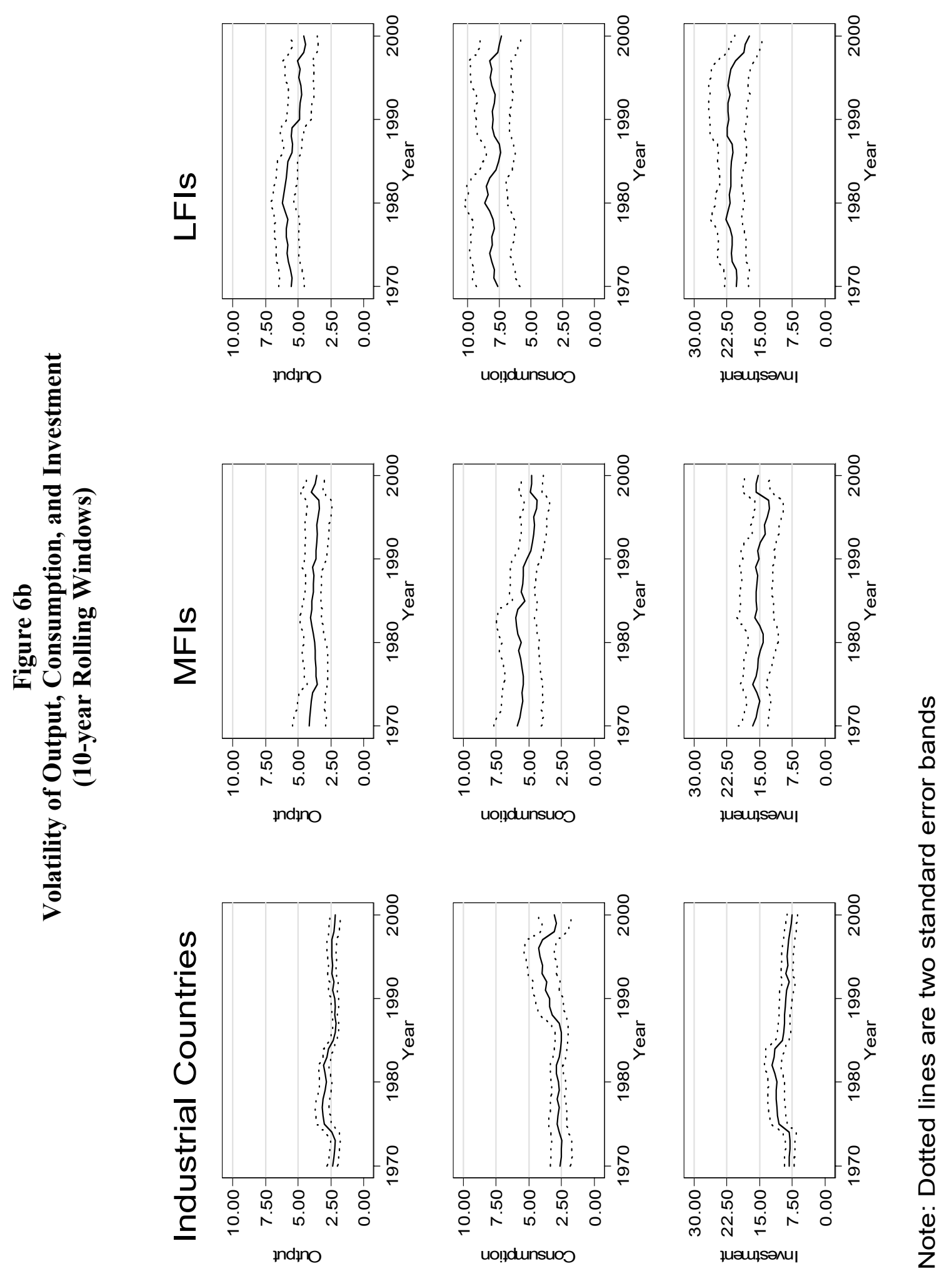



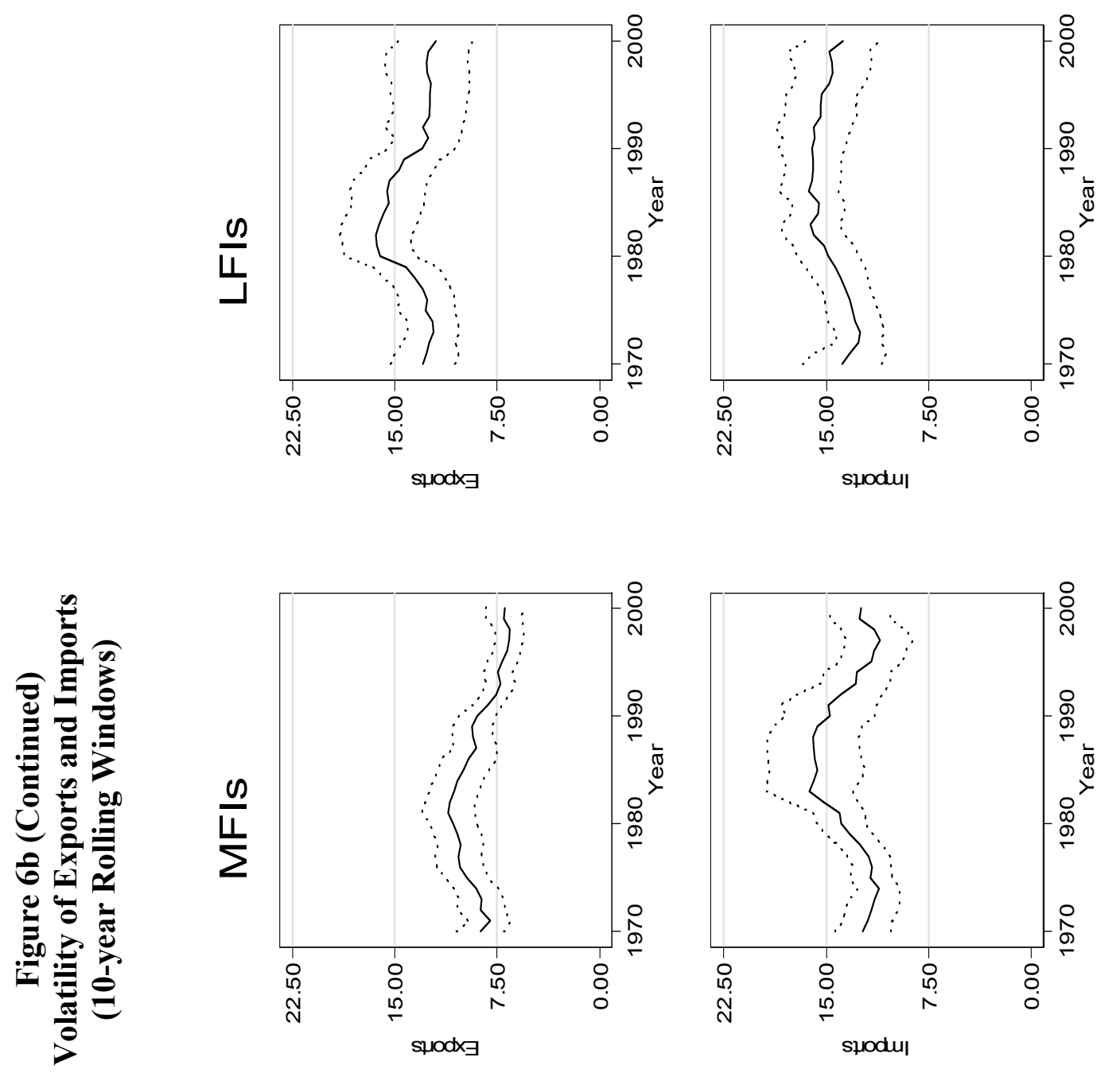

0
0
$\frac{1}{0}$
0
$\frac{1}{0}$
$\frac{1}{1}$
$\frac{1}{1}$
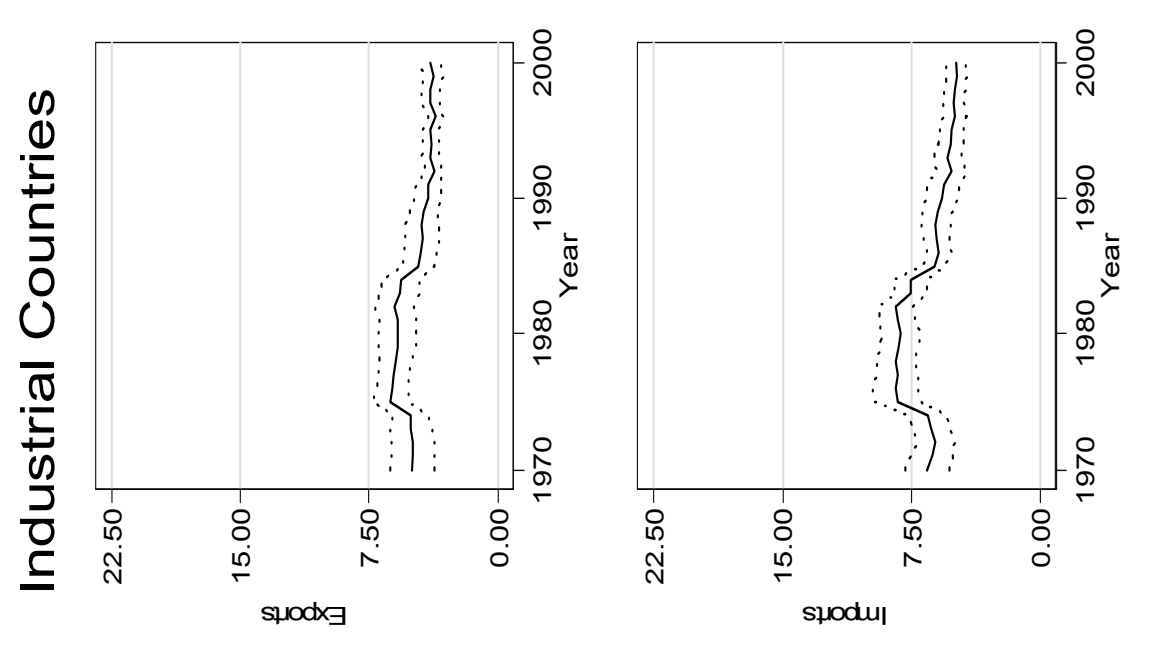

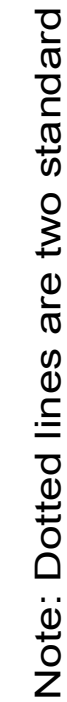


Figure 7

Growth and Volatility

(Simple Correlation, 1960-1985 and 1986-2000)

Full Sample
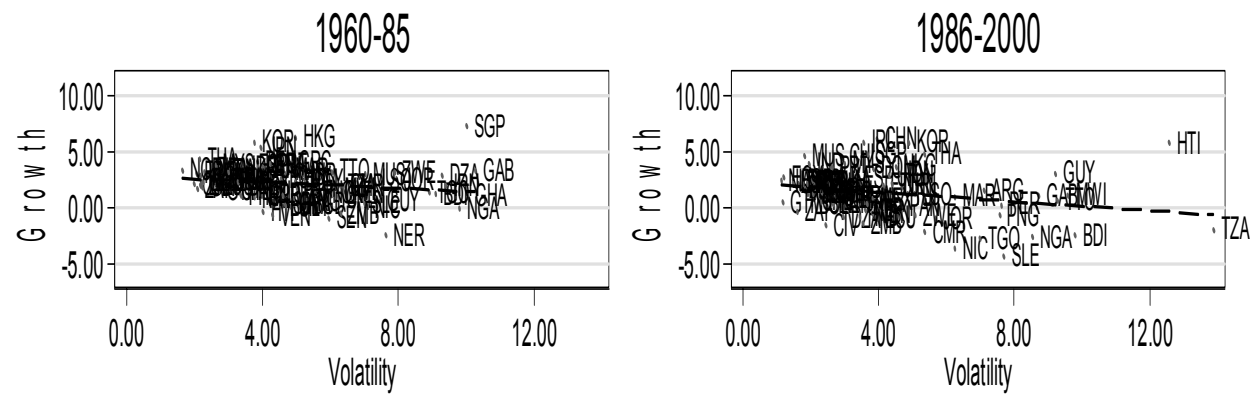

Industrial Countries
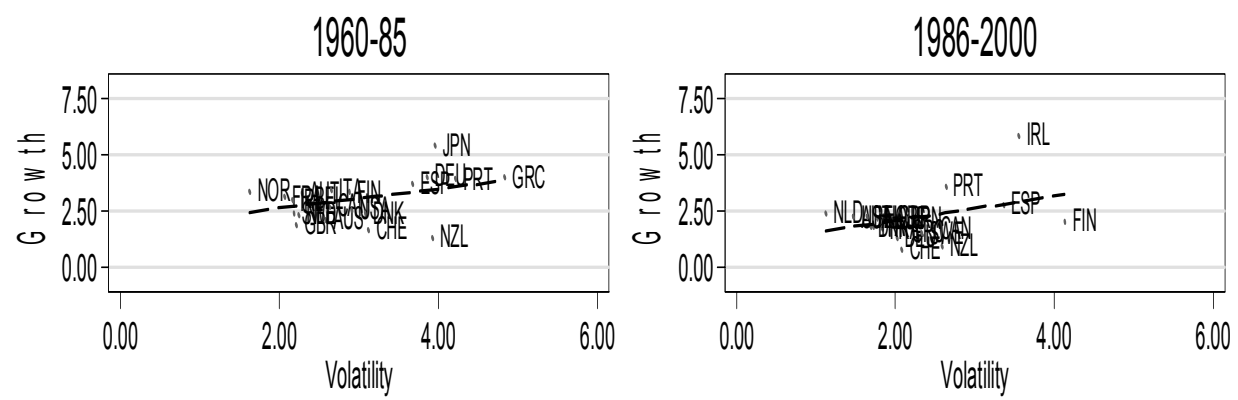

Developing Countries
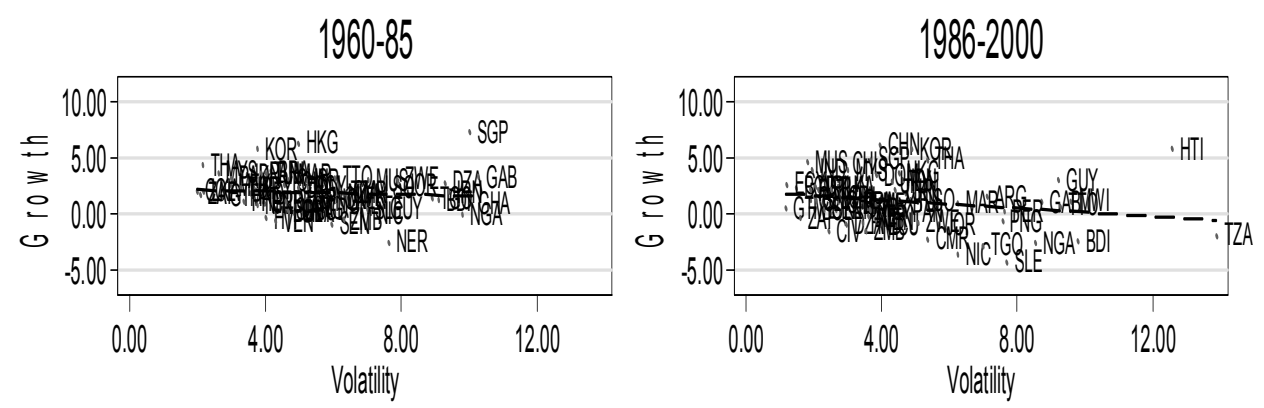

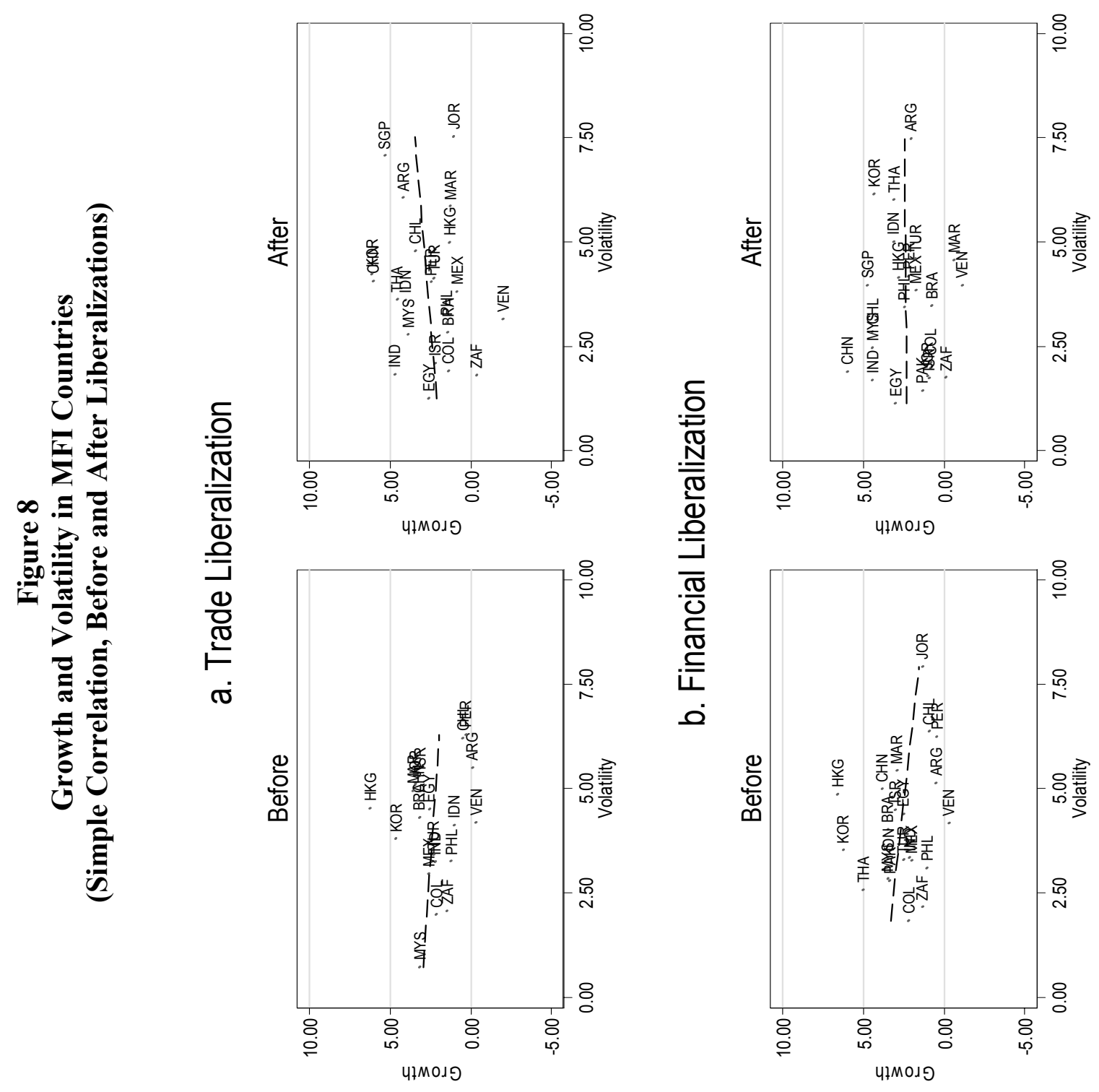
Figure 9

Output Growth: Before and After Liberalizations
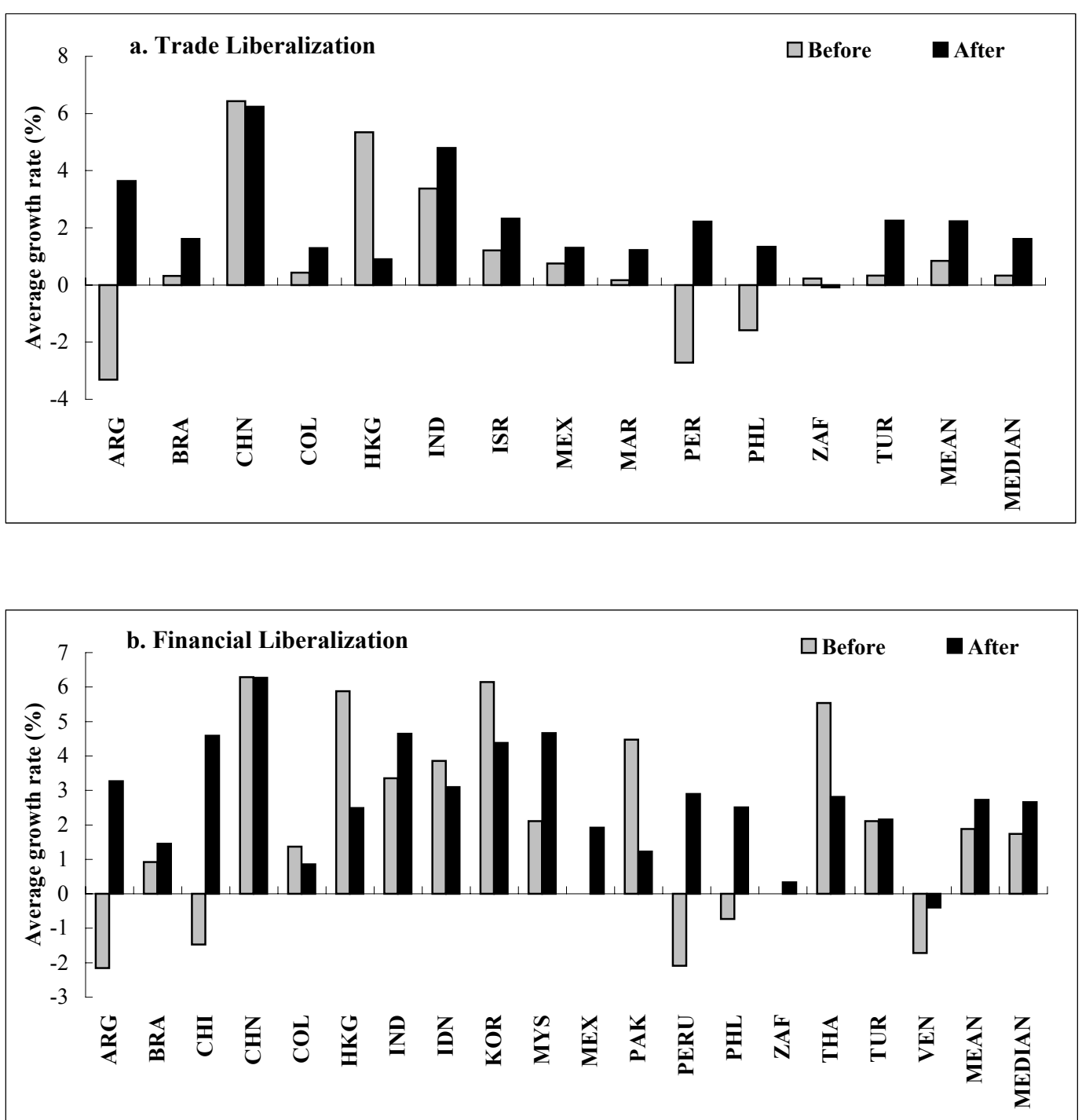

Notes: Average output growth of each country for the periods before and after liberalization is reported. 
Figure 10

Output Volatility: Before and After Liberalizations
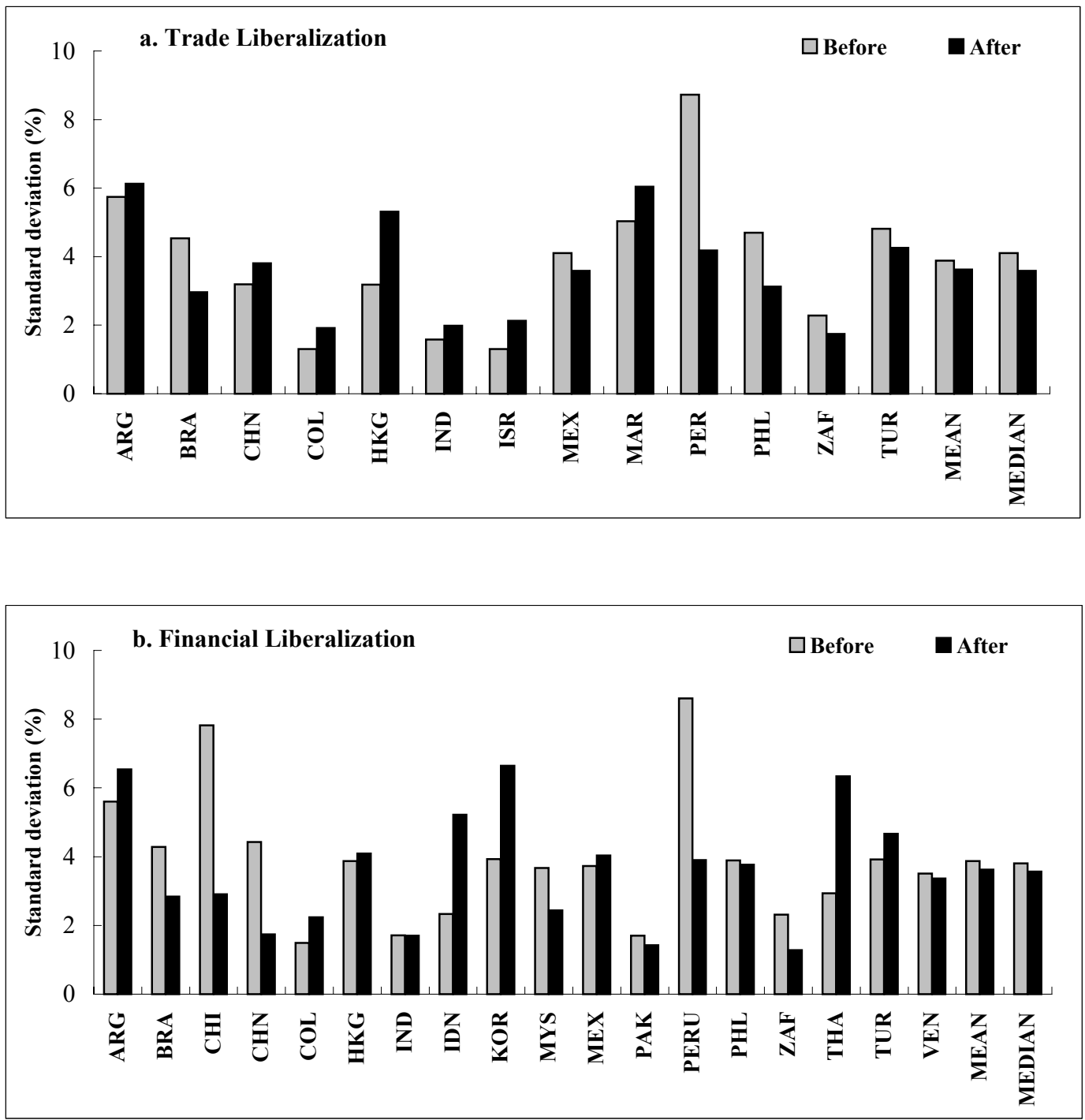

Notes: Volatility of output growth of each country for the periods before and after liberalization is reported. 

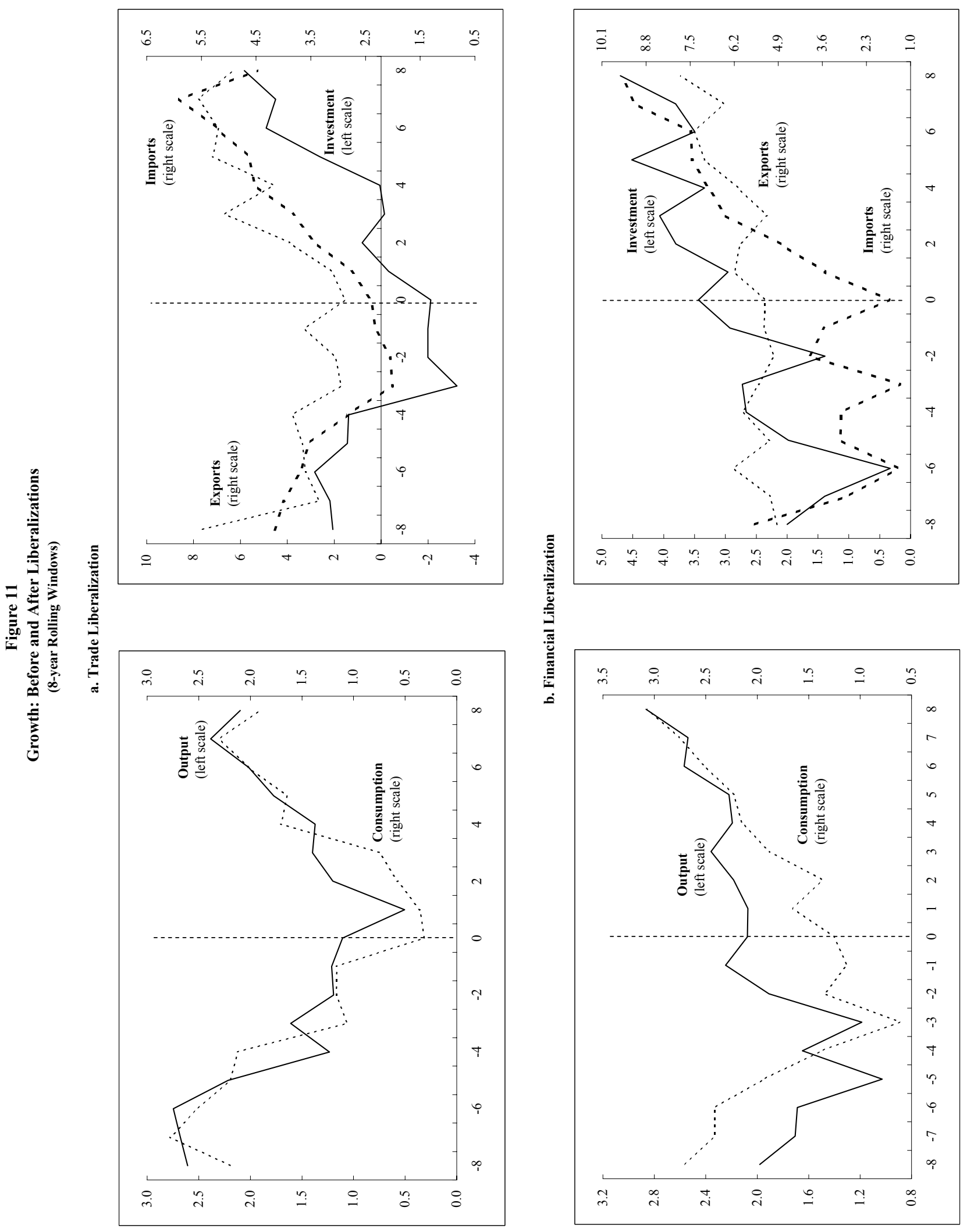

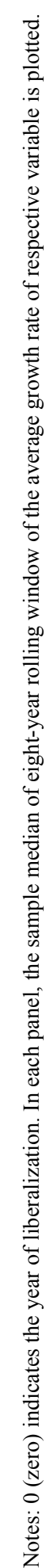



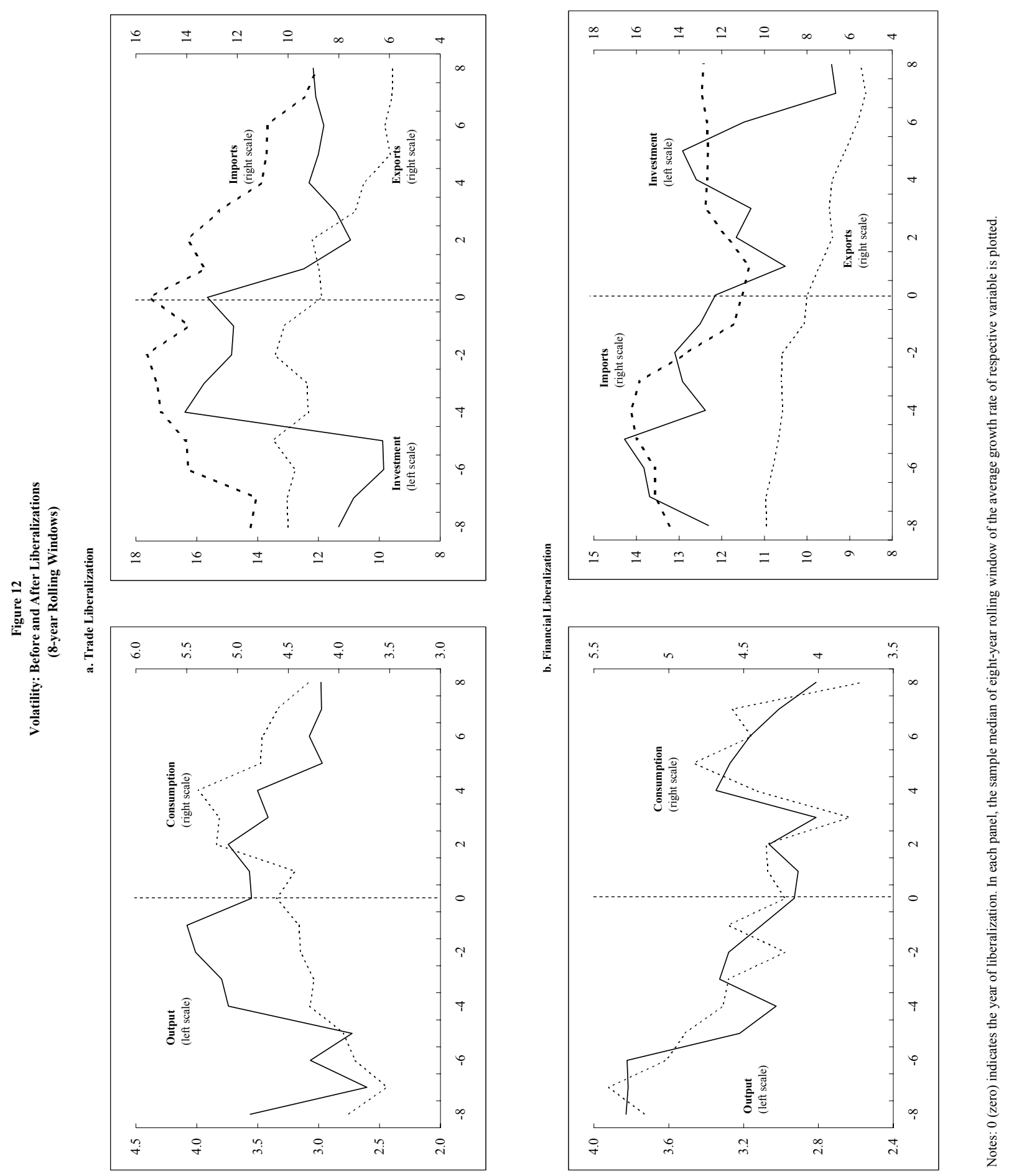